\title{
PENGUNGKAPAN TANGGUNG JAWAB SOSIAL DAN LINGKUNGAN PADA BANK SYARIAH DAN KONVENSIONAL BESERTA DETERMINANNYA
}

\author{
Dian Imanina Burhany \\ dian.imanina@polban.ac.id \\ Neneng Dahtiah \\ Ahmad Syarief \\ Politeknik Negeri Bandung
}

\begin{abstract}
Corporate social and environmental responsibility (CSER) disclosure in Indonesia is currently not optimal, including in banking sector, both sharia banks and conventional banks. Many things are determinants, including company characteristics and elements of corporate governance. This study aims to determine difference in CSER disclosure between sharia banks and conventional banks and their determinants. Determinants consist of company characteristics which include company size and profitability as well as corporate governance elements which include board of director size, independent director, and audit committee. Research sample is sharia banks and conventional banks that carry out CSER disclosure on website in 2018. Research data is secondary data accessed through the bank's website. Data is analyzed using content analysis, descriptive analysis, and multiple regression analysis. Study result found that statistically, there is no difference in CSER disclosure between sharia banks and conventional banks, but descriptively, disclosure in sharia banks is higher than conventional banks. Furthermore, determinant that influence positively is company characteristic in the form of company size (assets), while company characteristic in the form of profitability and corporate governance elements in the form of board of directos size, independent director, and audit committee have no effect on CSER disclosure.
\end{abstract}

Key words: company characteristic; corporate governance element; social and environmental responsibility disclosure; sharia bank; conventional bank.

\begin{abstract}
ABSTRAK
Pengungkapan tanggung jawab sosial dan lingkungan (TJSL) perusahaan di Indonesia saat ini belum maksimal, termasuk pada sektor perbankan, baik bank syariah maupun bank konvensional. Banyak hal yang menjadi determinan, di antaranya karakteristik perusahaan dan elemen tata kelola perusahaan. Penelitian ini bertujuan untuk mengetahui perbedaan pengungkapan TJSL antara bank syariah dan bank konvensional beserta determinannya. Determinan terdiri atas karakteristik perusahaan yang meliputi ukuran perusahaan dan profitabilitas serta elemen tata kelola perusahaan yang meliputi ukuran dewan direksi, direksi independen, dan komite audit. Sampel penelitian adalah bank syariah dan bank konvensional yang melakukan pengungkapan TJSL di website pada tahun 2018. Data penelitian adalah data sekunder yang diakses melalui website bank. Data dianalisis menggunakan analisis konten, analisis deskriptif, dan analisis regresi berganda. Hasil penelitian menemukan bahwa secara statistik, tidak ada perbedaan pengungkapan TJSL antara bank syariah dan bank konvensional, namun secara deskriptif, pengungkapan TJSL pada bank syariah lebih tinggi dibandingkan pada bank konvensional. Selanjutnya, determinan yang berpengaruh positif terhadap pengungkapan TJSL adalah karakteristik perusahaan berupa ukuran perusahaan (aset), sedangkan karakteristik perusahaan berupa profitabilitas serta elemen tata kelola perusahaan berupa ukuran dewan direksi, direksi independen, dan komite audit tidak berpengaruh terhadap pengungkapan TJSL.
\end{abstract}

Kata kunci: karakteristik perusahaan; elemen tata kelola perusahaan; pengungkapan tanggung jawab sosial dan lingkungan; bank syariah; bank konvensional. 


\section{PENDAHULUAN}

Paradigma perusahaan telah bergeser dari hanya sekedar memaksimalkan laba yang merupakan aspek ekonomi, menjadi ikut peduli terhadap aspek sosial dan lingkungan. Ini yang dikenal dengan istilah tanggung jawab sosial perusahaan atau corporate social responsibility (CSR). Tanggung jawab sosial meliputi banyak hal seperti tanggung jawab terhadap karyawan, masyarakat sekitar, lingkungan, dan berbagai pihak lainnya. Secara umum cakupannya adalah aspek sosial dan lingkungan sehingga sering juga disebut sebagai tanggung jawab sosial dan lingkungan.

Hal ini pada awalnya dipicu oleh tekanan masyarakat yang mulai merasakan dampak negatif dari keberadaan perusahaan. Bisnis dan perusahaan memang menciptakan kesejahteraan dan lapangan kerja bagi masyarakat, tetapi pada saat yang sama juga menimbulkan dampak negatif khususnya terhadap lingkungan (Alimullah, 2006). Tekanan juga berasal dari stakeholder lain seperti pemerintah, pelanggan, organisasi non pemerintah, bahkan karyawan perusahaan sendiri. Tekanan tersebut berbeda satu sama lain tergantung pada kepentingannya masing-masing, namun intinya mereka menginginkan perusahaan yang lebih peduli sehingga dapat mengurangi risiko mereka (Islam dan Deegan, 2008).

Karena adanya tekanan tersebut, perusahaan mulai melakukan tanggung jawab sosial dan lingkungan (TJSL) dengan mengalokasikan dana untuk berbagai aktivitas seperti pemberian layanan kesehatan gratis kepada masyarakat, pemberian beasiswa kepada pelajar dan mahasiswa, pelestarian lingkungan, perbaikan fasilitas umum, peningkatan kesejahteraan karyawan, dan lain sebagainya. Hal ini disebabkan karena perusahaan cenderung ingin memuaskan stakeholder karena membutuhkan dukungan untuk melanjutkan operasinya, sebagaimana dijelaskan oleh stakeholder theory (Jensen dan Meckling, 1976; Donaldson, 1999).
TJSL harus diungkapkan agar stakeholer mengetahuinya. Ini memperluas tanggung jawab manajemen dalam bidang akuntansi. Informasi akuntansi yang biasanya hanya terbatas pada laporan keuangan saja perlu dilengkapi lagi dengan informasi tambahan berupa pengungkapan TJSL. Pengungkapan TJSL adalah penyediaan informasi keuangan dan non-keuangan yang berkaitan dengan interaksi organisasi dengan lingkungan fisik dan sosialnya (Guthrie et al., 2008). Pengungkapan TJSL merupakan isu yang penting dalam dunia bisnis saat ini (Waller dan Lanis, 2009). Melalui pengungkapan TJSL, perusahaan dapat mengomunikasikan kepada stakeholder apakah mereka telah berperilaku sosial dan sejauh mana mereka menghormati masyarakat dan lingkungan (Habbash, 2016). Pengungkapan TJSL memainkan peran yang signifikan dalam bisnis karena dapat meningkatkan citra perusahaan dan menyediakan informasi yang berguna bagi pengambilan keputusan investasi (Friedman dan Miles, 2001; Deegan dan Blomquist, 2006). Perusahaan juga mengungkapkan informasi TJSL untuk mendapatkan respek dari publik atau untuk melegitimasi operasi bisnisnya (Deegan, 2002) sebagaimana dijelaskan oleh legitimacy theory. Menurut teori ini, perusahaan melakukan suatu aktivitas untuk mengesahkan aktivitasnya tersebut agar sejalan dengan keinginan masyarakat (Brammer dan Pavelin, 2006).

Saat ini tingkat pengungkapan TJSL perusahaan masih belum maksimal. Azim et al. (2011) melaporkan hanya 16\% perusahaan publik di Bangladesh yang melakukan pengungkapan TJSL. Informasi lain, tingkat pengungkapan tanggung jawab sosial perusahaan yang tercatat di Bursa Efek Indonesia hanya 33\% (Retno dan Priantinah, 2012) dan tingkat pengungkapan lingkungan pada perusahaan pertambangan umum hanya 49,70\% (Burhany, 2011). Sementara itu, sektor perbankan di Bangladesh hanya melaporkan 47,39\% informasi TJSL pada laporan tahunannya (Ullah dan Rahman, 
2015).

Masih rendahnya pengungkapan TJSL pada umumnya disebabkan oleh belum kuatnya regulasi sehingga sifatnya masih voluntary atau semi voluntary (Buhr dan Freedman, 2001; Burhany, 2011). Namun regulasi merupakan variabel eksternal yang tidak dapat dikendalikan oleh perusahaan. Maka beberapa peneliti menguji hubungan pengungkapan TJSL dengan beberapa variabel internal yang meliputi karakteristik perusahaan dan elemen tata kelola perusahaan. Karakteristik perusahaan yang ditemukan berhubungan atau berpengaruh terhadap pengungkapan TJSL di antaranya adalah ukuran perusahaan (Hackston dan Milne, 1996; Tagesson et al., 2009; Giannarakis, 2014; Habbash, 2016) dan profitabilitas (Giannarakis, 2014). Namun Habbash (2016) menemukan profitabilitas tidak berpengaruh terhadap pengungkapan TJSL. Sementara itu, elemen tata kelola perusahaan yang berpengaruh terhadap pengungkapan TJSL adalah ukuran dewan direksi (Esa dan Ghazali, 2012; Lone dan Khan, 2016), direksi independen (Khan, 2010; Lone dan Khan, 2016), dan komite audit (Said et al., 2009). Namun masih terdapat hasil yang berbeda yaitu ukuran dewan direksi (Giannarakis, 2014), direksi independen (Habbash, 2016), dan komite audit (Habbash, 2016) ditemukan tidak berhubungan dengan pengungkapan TJSL.

Sektor perbankan mulai menjadi perhatian karena dengan keuntungan dan dana yang dimiliki sebenarnya dapat memberikan kontribusi sosial dan lingkungan yang besar. Saat ini sektor perbankan semakin terlibat dalam inisiatif perlindungan dan pengelolaan lingkungan untuk mengurangi emisi karbon dan menjaga kelestarian lingkungan dengan memperkenalkan praktik yang disebut green banking (Shaumya dan Arulrajah, 2017). Meskipun tidak secara langsung, sektor perbankan memiliki andil dalam aspek lingkungan. Penggunaan energi (listrik dan air) dan kertas (yang berasal dari pepohonan), cukup tinggi pada sektor ini. Demikian juga dengan kepedulian yang ditunjukkan dalam bentuk charity kepada masyarakat membuktikan bahwa sektor ini memiliki andil yang besar dalam TJSL.

Regulasi yang berkaitan dengan TJSL untuk bank dan lembagan keuangan lain telah ada saat ini. Pada tanggal 27 Juli 2017, Otoritas Jasa Keuangan (OJK) telah mengeluarkan Peraturan Otoritas Jasa Keuangan (POJK) No. 51/POJK.03/2017 tentang Penerapan Keuangan Berkelanjutan bagi Lembaga Jasa Keuangan, Emiten, dan Perusahaan Publik. Pada Pasal 1 dijelaskan bahwa: "Tanggung Jawab Sosial dan Lingkungan yang selanjutnya disingkat TJSL adalah komitmen untuk berperan serta dalam pembangunan ekonomi berkelanjutan guna meningkatkan kualitas kehidupan dan lingkungan yang bermanfaat, baik bagi Perseroan sendiri, komunitas setempat, maupun masyarakat pada umumnya." Selanjutnya pada Pasal 2 ayat (1) diatur bahwa: "LJK, Emiten, dan Perusahaan Publik wajib menerapkan Keuangan Berkelanjutan dalam kegiatan usaha LJK, Emiten, dan Perusahaan Publik." Pada Pasal 8 ayat (1) diatur bahwa: "LJK yang diwajibkan melaksanakan TJSL wajib mengalokasikan sebagian dana TJSL untuk mendukung kegiatan penerapan Keuangan Berkelanjutan."

Pada POJK ini, pengungkapan TJSL diatur dalam Pasal 10. Pada ayat (1) ditetapkan bahwa: "LJK, Emiten, dan Perusahaan Publik wajib menyusun Laporan Keberlanjutan." Pada Pasal 12 ayat (1) disebutkan bahwa: "LJK, Emiten, dan Perusahaan Publik wajib mempublikasikan Laporan Keberlanjutan sebagaimana dimaksud dalam Pasal 10 ayat (1)" dan pada ayat (2) disebutkan bahwa: "Publikasi Laporan Keberlanjutan sebagaimana dimaksud pada ayat (1) wajib dilakukan melalui situs web LJK, Emiten, dan Perusahaan Publik paling lambat pada tanggal 30 April tahun berikutnya."

Beberapa literatur mengungkapkan bahwa perhatian sektor perbankan mengenai keberlanjutan agak lambat. Kolk et al. 
(2001) menemukan bahwa sektor keuangan dan jasa umum mengurangi informasi lingkungan karena menganggap dampak mereka terhadap lingkungan tidak seperti pada sektor manufaktur. Meskipun demikian, sektor perbankan sudah mulai memasukkan aspek lingkungan ini (Viganò dan Nicolai, 2009 dalam Vilar dan Simão, 2015). Pengungkapan TJSL pada sektor ini juga telah meningkat dalam beberapa tahun terakhir (Scholtens, 2009). Peningkatan pengungkapan tersebut dipicu oleh peningkatan pengeluaran bank untuk aktivitas TJSL (Ullah dan Rahman, 2015).

Selain bank konvensional, saat ini sektor perbankan diramaikan oleh bank syariah yaitu bank yang menjalankan operasinya berdasarkan prinsip syariah dalam agama Islam yaitu tidak mengandung bunga atau riba. Bank syariah menjadi alternatif yang cukup diminati dalam era modern saat ini dan menunjukkan pertumbuhan yang pesat dalam dua dekade terakhir (Farook et al., 2011). Sebagai negara berkembang dengan populasi muslim yang besar, Indonesia merupakan pasar yang prospektif untuk industri berbasis syariah termasuk bank syariah. Saat ini ada 13 bank syariah dan puluhan unit usaha syariah yang beroperasi di Indonesia. Berdasarkan pada nilai-nilai Islami tentang keadilan sosial dan akuntabilitas, bank syariah memiliki landasan yang kuat untuk melaksanakan dan mengungkapkan TJSL (Farook et al., 2011; Ilyas, 2018). Penelitian juga menemukan adanya perbedaan signifikan dalam pengungkapan TJSL antara bank Islam atau syariah dan bank konvensional (Aribi dan Gao, 2010), cukup tingginya tingkat pengungkapan aktivitas TJSL perusahaan berbasis syariah pada laporan tahunan (Yahya et al., 2004; Haniffa dan Hudaib, 2007), dan pengungkapan TJSL oleh bank Islam atau syariah umumnya tumbuh dengan baik di Malaysia dan Indonesia (Amran et al., 2017).

Maka, berdasarkan uraian yang menunjukkan masih relatif rendahnya tingkat pengungkapan TJSL, adanya regulasi POJK
No. 51/POJK.03/2017 yang mewajibkan lembaga keuangan untuk melaksanakan dan mengungkapkan TJSL, serta masih adanya research gap dari penelitian terdahulu, penelitian ini bertujuan untuk mengetahui perbedaan pengungkapan TJSL antara bank syariah dan bank konvensional beserta determinannya. Kebaruan penelitian ini dibandingkan penelitian terdahulu adalah pada pengambilan periode pengungkapan TJSL untuk tahun 2018, yaitu setelah terbitnya POJK No. 51/POJK.03/2017. Dengan demikian dapat dilihat nantinya, apakah dengan adanya regulasi tersebut, determinan yang terdiri atas karakteristik perusahaan yang meliputi ukuran perusahaan dan profitabilitas serta elemen tata kelola perusahaan yang meliputi ukuran dewan direksi, direksi independen, dan komite audit, berpengaruh terhadap pengungkapan TJSL.

\section{TINJAUAN TEORETIS \\ Stakeholder Theory}

Stakeholder theory digunakan sebagai dasar untuk menganalisis kelompok kepada siapa perusahaan harus bertanggung jawab. Dalil utama teori ini adalah bahwa keberhasilan perusahaan sangat bergantung pada keberhasilan manajemen dalam mengelola hubungan dengan stakeholder-nya (Elijido-Ten, 2007). Istilah stakeholder pertama kali diperkenalkan oleh Stanford Research Institute untuk menjelaskan "suatu kelompok yang tanpa dukungannya, organisasi akan berhenti" (Freeman, 1984 dalam Elijido-Ten, 2007). Dengan sudut pandang ini maka anggapan bahwa keberhasilan perusahaan hanya bergantung pada maksimalisasi kesejahteraan pemegang saham (shareholder) menjadi tidak relevan lagi, karena keberadaan suatu entitas perusahaan pada dasarnya merupakan kontrak antara perusahaan itu dan berbagai pihak lain yang disebut stakeholder (Jensen dan Meckling, 1976).

Stakeholder theory diturunkan dari sociopolitical theory yang menjelaskan bahwa 
tindakan suatu perusahaan dilakukan atas tekanan sosial dan politik yang dihadapi. Untuk menghadapi tekanan itu maka perusahaan akan melakukan pengungkapan informasi agar dapat mengubah persepsi stakeholder terhadapnya (Patten, 2002). Stakeholder memiliki hak untuk mendapatkan informasi yang lebih spesifik untuk kepentingan pengambilan keputusannya dan perusahaan harus menyediakan informasi itu. Informasi merupakan media utama yang dapat digunakan organisasi untuk mengelola (atau memanipulasi) stakeholder dengan tujuan untuk memperoleh dukungan dan penerimaan atau untuk mengalihkan penentangan dan penolakan (Gray et al., 1995). Organisasi akan bertindak berdasarkan tuntutan stakeholder-nya. Jika stakeholder menuntut perusahaan untuk mengungkapkan informasi TJSL maka organisasi atau perusahaan akan melakukannya (Vilar dan Simão, 2015).

\section{Legitimacy Theory}

Sebagaimana halnya stakeholder theory, legitimacy theory juga diturunkan dari sociopolitical theory dan digunakan untuk menjelaskan mengapa suatu perusahaan melakukan suatu tindakan tertentu (Farache dan Perks, 2010; Gamerschlag et al., 2011). Inti dari teori ini adalah bahwa perusahaan memiliki keinginan untuk tampil sebagai perusahaan yang baik yang menggunakan sebagian dari sumber dayanya untuk memberi manfaat kepada masyarakat dan bukan hanya kepada para pemegang sahamnya. Hal ini dilakukan agar mereka tidak dikenakan biaya politik jika tindakannya tidak disukai oleh masayarakat (Deegan dan Rankin, 1996; Hooghiemstra, 2000). Dengan melakukan pengungkapan TJSL, perusahaan mencoba membentuk citra positif dan menunjukkan identitas bertanggung jawab secara sosial. Perusahaan ditekan untuk beroperasi sesuai dengan prinsip sosial dan masyarakat bertindak sebagai pihak yang mengamati tindakan tersebut. Adanya kontrak sosial semacam itu merupakan salah satu cara perusahaan untuk melegitimasi operasinya. Sebagai hasil dari tekanan tersebut, perusahaan melaporkan jumlah informasi yang lebih banyak mengenai TJSL ketika mereka menghadapi sorotan publik dan cenderung mengungkapkan fakta positif dengan nada memuji untuk melegitimasi perilaku mereka (Deegan dan Gordon, 1996).

Pengomunikasian aktivitas TJSL menjadi saluran untuk menciptakan, memulihkan, atau mempertahankan legitimasi perusahaan. Jadi, jika stakeholder theory lebih fokus pada dampak kelompok atau individu terhadap perilaku organisasi, maka legitimacy theory mengintegrasikan visi bahwa masyarakat, kebijakan dan ekonomi tidak dapat dipisahkan (aspek ekonomi, lingkungan dan sosial tidak dapat diinterpretasikan secara terpisah). Membuat informasi sosial dan lingkungan tersedia secara sukarela merupakan respon terhadap keberadaan individu atau kelompok yang tertarik pada perilaku organisasi (Moneva dan Llena, 2000). Sebuah organisasi akan mengidentifikasi stakeholder yang paling signifikan dan secara positif mengondisikan persepsi tentang tindakannya, agar mendapatkan legitimasi untuk eksis dan beroperasi (Vilar dan Simão, 2015).

\section{Pengungkapan Tanggung Jawab Sosial dan Lingkungan Secara Umum dan Menurut Syariah}

Isi atau konten pengungkapan TJSL sangat bervariasi antara satu perusahaan dengan perusahaan lainnya tergantung pada aktivitas TSJL yang dilakukannya. Perusahaan yang memiliki dampak lingkungan seperti perusahaan manufaktur dan pertambangan biasanya melakukan lebih banyak aktivitas TJSL pada aspek lingkungan, sehingga juga mengungkapkan lebih banyak informasi mengenai aspek tersebut. Sedangkan perusahaan jasa lebih menekankan aktivitas dan pengungkapan TJSL pada aspek sosial. Hal lain yang menyebabkan bervariasinya konten pengungkapan TJSL adalah karena praktik ini merupakan konsep yang masih berkembang (Alam et al., 2010). 
GRI (Global Reporting Initiative) Sustainability Reporting Guidelines yang merupakan pedoman penyusunan laporan keberlanjutan (sering juga disebut laporan CSR) yang identik dengan TJSL, memberikan acuan pengungkapan yang meliputi aspek ekonomi, lingkungan, karyawan, hak asasi manusia, masyarakat, dan tanggung jawab produk (GRI, 2015). Indikator pengungkapan TJSL GRI terus direvisi dan saat ini sudah berada pada generasi keempat atau GRI 4.0. Selain laporan keberlanjutan, tempat pengungkapan TJSL lainnya adalah laporan tahunan (Deegan dan Rankin, 1996; Guthrie et al., 2008). Laporan tahunan dapat dipandang sebagai sarana di mana perusahaan menyampaikan citranya kepada publik melalui laporan yang bersifat sukarela (Guthrie dan Abeysekera, 2006). Pada era teknologi informasi saat ini, sebagian besar perusahaan menyediakan laporan tersebut di website-nya.

Fondasi teoritis TJSL yang walaupun berasal dari Barat, namun sangat mirip dengan doktrin syariah Islam tentang keadilan sosial dan akuntabilitas (Ilyas, 2018). Tujuan perusahaan beroperasi bukan semata-mata untuk mengejar keuntungan tapi juga menjalankan fardhu kifayah untuk bekerja menuju tujuan mulia seperti memerangi kemiskinan dan mengangkat orang yang kurang beruntung dan tertindas (Yusuf dan Bahari, 2015). Tanggung jawab sosial dalam Islam harus didasarkan pada konsep Islami bahwa manusia harus menjaga keseimbangan dalam kehidupan (Aribi dan Gao, 2010). Cara terbaik menjalankan bisnis dalam Islam adalah dengan meningkatkan kepuasan pelanggan dan memperhatikan relasi sosial (Rashid et al., 2013). Islam juga mengatur bahwa manusia harus menjaga kelestarian lingkungan (Aribi dan Gao, 2010).

Menerapkan nilai-nilai syariah sudah dengan sendirinya menerapkan indikatorindikator dalam TJSL karena praktik TJSL konsisten dengan prinsip dan nilai syariah atau nilai Islami yang ditetapkan dalam $\mathrm{Al}$
Quran (Dusuki dan Abdullah, 2007). Al Quran mengatur agar manusia tidak membuat kerusakan di muka bumi dan hidup secara harmonis dengan makhluk lainnya. Dalam Surat Al Qashash ayat (77) diserukan kepada manusia: "Dan carilah pada apa yang telah dianugerahkan Allah kepadamu (kebahagiaan) negeri akhirat, dan janganlah kamu melupakan bagianmu dari (kenikmatan) duniawi dan berbuat baiklah (kepada orang lain) sebagaimana Allah telah berbuat baik kepadamu, dan janganlah kamu berbuat kerusakan di (muka) bumi. Sesungguhnya Allah tidak menyukai orangorang yang berbuat kerusakan."

Nilai Islami mendukung perlunya bank syariah melakukan dan mengungkapkan TJSL (Farook et al., 2011). Aribi dan Gao (2010) menemukan bahwa ada perbedaan signifikan dalam pengungkapan TJSL antara bank Islam atau syariah dan bank konvensional. Yahya et al. (2004); Haniffa dan Hudaib (2007), menemukan tingkat pengungkapan aktivitas TJSL perusahaan berbasis syariah pada laporan tahunan cukup tinggi. Amran et al. (2017) menemukan pengungkapan TJSL oleh bank Islam atau syariah umumnya tumbuh dengan baik di Malaysia dan Indonesia, maka dapat dirumuskan hipotesis penelitian sebagai berikut:

$\mathrm{H}_{1}$ : Ada perbedaan pengungkapan TJSL antara bank syariah dan bank konvensional.

\section{Karakteristik Perusahaan sebagai Deter- minan Pengungkapan Tanggung Jawab Sosial dan Lingkungan}

Karakteristik perusahaan yang terdiri atas beberapa elemen merupakan salah satu determinan pengungkapan TJSL. Hackston dan Milne (1996); Tagesson et al. (2009) menemukan hubungan positif antara karakteristik berupa ukuran perusahaan dan jumlah informasi TJSL yang diungkapkan. Giannarakis (2014) menemukan bahwa ukuran perusahaan dan profitabilitas berhubungan positif dengan pengungkapan 
TJSL. Sementara itu, Habbash (2016) menemukan ukuran perusahaan dan umur perusahaan berpengaruh positif, sedangkan firm leverage berpengaruh negatif terhadap pengungkapan TJSL. Penelitian lainnya oleh Kolk (2003) menemukan tipe industri berpengaruh terhadap pengungkapan TJSL.

Perusahaan yang ukurannya lebih besar cenderung melakukan pengeluaran TJSL yang lebih besar pula kemudian mengungkapkannya. Ini disebabkan karena perusahaan yang berukuran besar memiliki aset yang besar pula untuk dialokasikan pada aktivitas TJSL (Cowen et al., 1987). Umur perusahaan biasanya sudah tergambar pada ukuran perusahaan. Perusahaan dengan profitabilitas yang lebih besar dengan sendirinya memiliki keleluasaan dana untuk disisihkan ke dalam aktivitas TJSL dan mengungkapkannya. Financial leverage terjadi akibat perusahaan menggunakan sumber dana dari utang yang menyebabkan perusahaan harus menanggung beban tetap berupa bunga, sehingga akan berpengaruh negatif terhadap pengungkapan TJSL. Pada bank syariah tidak dikenal adanya bunga sehingga variabel ini tidak diteliti. Tipe industri dalam penelitian ini adalah homogen sehingga tidak diteliti, maka dapat dirumuskan hipotesis penelitian sebagai berikut:

$\mathrm{H}_{2}$ : Karakteristik perusahaan berupa ukuran perusahaan berpengaruh positif terhadap pengungkapan TJSL pada bank syariah dan bank konvensional.

$\mathrm{H}_{3}$ : Karakteristik perusahaan berupa profitabilitas berpengaruh positif terhadap pengungkapan TJSL pada bank syariah dan bank konvensional.

\section{Elemen Tata Kelola Perusahaan sebagai Determinan Pengungkapan Tanggung Jawab Sosial dan Lingkungan}

Tata kelola perusahaan menyangkut organ-organ yang terkait dalam pengelolaan perusahaan. Elemen tata kelola yang ditemukan berhubungan atau berpengaruh positif terhadap luas pengungkapan TJSL adalah yang terkait dengan dewan direksi.
Esa dan Ghazali (2012); Giannarakis (2014), menemukan bahwa ukuran dewan direksi berhubungan positif dengan luas pengungkapan TJSL. Lone dan Khan (2016) menemukan bahwa ukuran dewan direksi, direktur independen, dan direktur wanita berpengaruh positif terhadap pengungkapan TJSL. Khan (2010) menemukan bahwa direktur non-eksekutif dan anggota direksi berkebangsaan asing berpengaruh positif terhadap pengungkapan TJSL. Ukuran dewan direksi yang lebih besar (jumlah direksi lebih banyak) diyakini merupakan kekuatan yang akan mendorong diungkapkannya TJSL. Direksi independen atau direktur noneksekutif juga diyakini merupakan determinan pengungkapan TJSL karena berasal dari luar perusahaan sehingga dapat bersikap lebih tegas dibandingkan direksi yang berasal dari dalam perusahaan. Direktur wanita tidak relevan dalam penelitian ini karena sebagian besar bank masih didominasi oleh direktur pria. Direktur berkebangsaan asing hampir tidak ada karena bank yang diteliti adalah bank nasional.

Elemen tata kelola perusahaan lainnya yang berpengaruh terhadap pengungkapan TJSL adalah komite audit. Said et al. (2009) menemukan bahwa komite audit berpengaruh positif terhadap luas pengungkapan TJSL. Hal ini disebabkan karena komite audit merupakan organ pengawas yang diharapkan dapat mendorong perusahaan melakukan best practices termasuk pengungkapan TJSL, maka dapat dirumuskan hipotesis penelitian sebagai berikut:

$\mathrm{H}_{4}$ : Elemen tata kelola perusahaan berupa ukuran dewan direksi berpengaruh positif terhadap pengungkapan TJSL pada bank syariah dan bank konvensional.

$\mathrm{H}_{5}$ : Elemen tata kelola perusahaan berupa direksi independen berpengaruh positif terhadap pengungkapan TJSL pada bank syariah dan bank konvensional.

$\mathrm{H}_{6}$ : Elemen tata kelola perusahaan berupa komite audit berpengaruh positif terhadap pengungkapan TJSL pada bank syariah dan bank konvensional. 


\section{METODE PENELITIAN}

\section{Tipe Penelitian}

Penelitian ini merupakan penelitian deskriptif komparatif yang mendeskripsikan variabel pengungkapan TJSL pada bank syariah dan bank konvensional kemudian membandingkannya. Penelitian ini juga merupakan penelitian kuantitatif yang menguji pengaruh antar variabel.

\section{Operasionalisasi Variabel Penelitian}

Variabel penelitian ini terdiri atas variabel independen karakteristik perusahaan yang meliputi ukuran perusahaan dan profitabilitas, tata kelola perusahaan yang meliputi ukuran dewan direksi, direksi independen, dan komite audit, serta variabel dependen pengungkapan TJSL. Operasionalisasi variabel independen dilakukan dengan merujuk pada penelitian sebelumnya oleh Said et al. (2009); Giannarakis (2014); Ullah dan Rahman (2015); Habbash (2016), sedangkan variabel dependen merujuk pada indikator pengungkapan TJSL GRI 4.0 yang sejalan dengan indikator pengungkapan yang diatur pada POJK Nomor 51/POJK. 03/2017.

Tabel 1

Operasionalisasi Variabel

\begin{tabular}{ll}
\hline \multicolumn{1}{c}{ Variabel } & \multicolumn{1}{c}{ Indikator } \\
\hline Ukuran Perusahaan $\left(\mathrm{X}_{1}\right)$ & Jumlah aset \\
Profitabilitas $\left(\mathrm{X}_{2}\right)$ & Return on assets $(\mathrm{ROA})$ \\
Ukuran dewan direksi $\left(\mathrm{X}_{3}\right)$ & Jumlah direksi \\
Direksi independen $\left(\mathrm{X}_{4}\right)$ & $\begin{array}{l}\text { Jumlah direksi independen dibandingkan jumlah } \\
\text { seluruh direksi }\end{array}$ \\
$\begin{array}{l}\text { Komite audit }\left(\mathrm{X}_{5}\right) \\
\begin{array}{l}\text { Pengungkapan tanggung jawab sosial } \\
\text { dan lingkungan }(\mathrm{Y})\end{array}\end{array}$ & Jumlah anggota komite audit \\
\hline
\end{tabular}

\section{Populasi dan Sampel Penelitian}

Populasi penelitian ini adalah bank umum yaitu bank syariah dan bank konvensional di Indonesia. Jumlah bank syariah di Indonesia adalah 13 bank sedangkan jumlah bank konvensional adalah 70 bank. Sampel diambil secara purposive yaitu bank syariah dan bank konvensional yang melakukan pengungkapan TJSL pada laporan tahunan atau laporan keberlanjutan (sustainability report) tahun 2018 yang dipublikasikan pada website-nya. Bank syariah yang memenuhi kriteria ini adalah sebanyak 11 bank dan bank konvensional sebanyak 50 bank, sehingga jumlah sampel keseluruhan adalah 61 bank.

\section{Data dan Teknik Pengumpulan Data}

Semua data penelitian merupakan data sekunder yang dikumpulkan melalui website bank yang bersangkutan.

\section{Metode Analisis Data dan Pengujian Hipotesis}

Analisis data menggunakan analisis konten (content analysis), analisis deskriptif, dan analisis regresi berganda. Analisis konten dilakukan dengan mempelajari konten atau isi laporan keberlanjutan atau laporan tahunan bank untuk menentukan adanya indikator atau item pengungkapan TJSL, analisis deskriptif adalah untuk mendeskripsikan profil variabel, dan analisis regresi berganda untuk memprediksi pengaruh variabel independen terhadap variabel dependen. Model persamaan regresi berganda yang digunakan adalah: $Y=\beta_{0}+\beta_{1} X_{1}+\beta_{2} X_{2}+\beta_{3} X_{3}+\beta_{4} X_{4}+\beta_{5} X_{5}+\varepsilon$

Pengujian hipotesis dilakukan dengan uji-z untuk menguji perbedaan serta uji-t untuk menguji pengaruh. Sebelum dilakukan pengujian hipotesis, terlebih dahulu dilakukan uji asumsi klasik yang mendasari 
analisis regresi berganda.

\section{ANALISIS DAN PEMBAHASAN Statistik Deskriptif}

Statistik deskriptif data variabel penelitian disajikan pada Tabel 2. Tabel 2 menunjukkan bahwa dari 61 bank, baik bank syariah maupun bank konvensional, ukuran perusahaan berdasarkan aset memiliki nilai minimun Rp903 miliar, nilai maksimum Rp1.124 triliun, nilai rata-rata Rp8,29 triliun, dan nilai standar deviasi Rp193,5 triliun. Karena nilai rata-rata lebih kecil daripada nilai standar deviasi maka berarti data variabel ukuran perusahaan berdasarkan asset sangat bervariasi. Sementara itu, profitabilitas berdasarkan ROA memiliki nilai minimun $-0,1077$ atau $-10,77 \%$ (rugi), nilai maksimum 0,0550 atau $5,50 \%$, nilai ratarata 0,007289 atau $0,7289 \%$, dan nilai standar deviasi 0,0247941 atau 2,47941\%. Karena nilai rata-rata lebih kecil daripada nilai standar deviasi maka berarti data variabel profitabilitas berdasarkan ROA sangat bervariasi.

Tabel 2

Statistik Deskriptif Data Variabel Penelitian

\begin{tabular}{|c|c|c|c|c|c|c|c|}
\hline No. & $\begin{array}{c}\text { Kode } \\
\text { Variabel }\end{array}$ & Nama Variabel & $\mathbf{N}$ & Minimum & Maksimum & Rata-rata & $\begin{array}{l}\text { Standar } \\
\text { Deviasi }\end{array}$ \\
\hline 1. & $\mathrm{X}_{1}$ & $\begin{array}{l}\text { Ukuran Perusahaan- } \\
\text { Aset }\end{array}$ & 61 & $\begin{array}{l}903 \text { miliar } \\
\text { rupiah }\end{array}$ & $\begin{array}{c}1.124 \\
\text { triliun } \\
\text { rupiah }\end{array}$ & $\begin{array}{r}8,29 \\
\text { triliun } \\
\text { rupiah }\end{array}$ & $\begin{array}{r}193,5 \\
\text { triliun } \\
\text { rupiah }\end{array}$ \\
\hline 2. & $X_{2}$ & Profitabilitas-ROA & 61 & $-0,1077$ & 0,0550 & 0,007289 & 0,0247941 \\
\hline 3. & $X_{3}$ & Ukuran Dewan Direksi & 61 & 3 & 12 & 5,93 & 2,387 \\
\hline 4. & $\mathrm{X}_{4}$ & Direksi Independen & 61 & 0,0000 & 1,0000 & 0,058102 & 0,1466333 \\
\hline 5. & $X_{5}$ & Komite Audit & 61 & 2 & 7 & 3,82 & 1,148 \\
\hline 6. & Y & Pengungkapan TJSL & 61 & 0,0516 & 0,5871 & 0,269907 & 0,1408662 \\
\hline
\end{tabular}

Sumber: Data hasil penelitian, diolah (2019)

Data variabel dewan direksi memiliki nilai minimum 3 (yang berarti bank tersebut memiliki 3 orang direksi), nilai maksimum 12 (yang berarti bank tersebut memiliki 12 orang direksi), nilai rata-rata 5,93 dan nilai standar deviasi 2,387. Karena nilai rata-rata lebih besar daripada nilai standar deviasi maka berarti data variabel dewan direksi relatif sama atau tidak terlalu bervariasi. Data variabel direksi independen memiliki nilai minimum 0,0000 (yang berarti bank tersebut tidak memiliki satu orangpun direksi independen), nilai maksimum 1,0000 atau 1 (yang berarti semua direksi pada bank tersebut adalah direksi independen yang berasal dari luar), nilai rata-rata 0,058102 dan nilai standar deviasi 0,1466333. Karena nilai rata-rata lebih kecil daripada nilai standar deviasi maka berarti data variabel direksi independen sangat bervariasi. Data variabel independen terakhir yaitu komite audit memiliki nilai minimum 2 (yang berarti bank tersebut memiliki 2 orang komisioner di komite audit), nilai maksimum 7 (yang berarti bank tersebut memiliki 7 orang komisioner di komite audit), nilai rata-rata 3,82 dan nilai standar deviasi 1,148. Karena nilai rata-rata lebih besar daripada nilai standar deviasi maka berarti data variabel komite audit relatif sama atau tidak terlalu bervariasi. Akhirnya, data variabel dependen pengungkapan TJSL memiliki nilai minimum 0,0516 atau 5,16\% (yang berarti bank tersebut mengungkapkan informasi tanggung jawab sosial dan lingkungan sebanyak $5,16 \%$ ), nilai maksimum 0,5871 atau $58,71 \%$ (yang berarti bank tersebut mengungkapkan informasi tanggung jawab sosial dan lingkungan sebanyak 58,71\%), nilai rata-rata 0,269907 atau 26,99\% (yang berarti rata-rata bank mengungkapkan informasi tanggung jawab sosial dan lingkungan sebanyak 
26,99\%) dan nilai standar deviasi 0,1408662 atau $14,09 \%$. Karena nilai rata-rata lebih besar daripada nilai standar deviasi maka berarti data variabel pengungkapan TJSL tidak terlalu bervariasi.

Deskripsi Nilai Indeks Rata-rata Pengungkapan Tanggung Jawab Sosial dan Lingkungan
Pada Tabel 3 berikut dideskripsikan nilai indeks rata-rata pengungkapan TJSL pada bank syariah dan bank konvensional. Nilai ini diperoleh dari hasil analisis konten dengan cara membandingkan pengungkapan yang dilakukan oleh bank dengan 155 standar atau indikator pengungkapan menurut GRI 4.0.

Tabel 3

Nilai Indeks Rata-rata Pengungkapan Tanggung Jawab Sosial dan Lingkungan

\begin{tabular}{|c|c|c|c|}
\hline \multirow{2}{*}{ Standar } & \multirow{2}{*}{ Indikator } & \multicolumn{2}{|c|}{ Nilai Rata-rata } \\
\hline & & BS & BK \\
\hline \multicolumn{4}{|c|}{ PENGUNGKAPAN UMUM (GENERAL) } \\
\hline \multicolumn{4}{|c|}{ PROFIL ORGANISASI (ORGANIZATIONAL PROFILE) } \\
\hline G1 & Nama organisasi & 1,00 & 1,00 \\
\hline G2 & Kegiatan, merek, produk, dan jasa & 1,00 & 0,86 \\
\hline G3 & Lokasi kantor pusat & 1,00 & 0,68 \\
\hline G4 & Lokasi operasi & 0,91 & 0,58 \\
\hline G5 & Kepemilikan dan bentuk hukum & 1,00 & 0,90 \\
\hline G6 & Pasar yang dilayani & 1,00 & 0,64 \\
\hline G7 & Skala organisasi & 0,36 & 0,60 \\
\hline G8 & Informasi mengenai karyawan dan pekerja lainnya & 1,00 & 0,52 \\
\hline G9 & Rantai pasokan & 0,73 & 0,36 \\
\hline G10 & $\begin{array}{l}\text { Perubahan signifikan pada organisasi dan rantai } \\
\text { pasokannya }\end{array}$ & 0,82 & 0,66 \\
\hline G11 & Pendekatan atau Prinsip Pencegahan & 1,00 & 0,70 \\
\hline G12 & Inisiatif eksternal & 0,91 & 0,68 \\
\hline \multirow[t]{2}{*}{ G13 } & Keanggotaan asosiasi & 0,55 & 0,46 \\
\hline & Sub jumlah & 11,27 & 8,64 \\
\hline \multicolumn{4}{|c|}{ STRATEGI (STRATEGY) } \\
\hline G14 & Pernyataan dari pembuat keputusan senior & 1,00 & 0,88 \\
\hline \multirow[t]{2}{*}{ G15 } & Dampak penting, risiko, dan peluang & 0,09 & 0,46 \\
\hline & Sub jumlah & 1,09 & 1,34 \\
\hline \multicolumn{4}{|c|}{ ETIKA DAN INTEGRITAS (ETHICS AND INTEGRITY) } \\
\hline G16 & Nilai, prinsip, standar, dan norma perilaku & 0,91 & 0,70 \\
\hline \multirow[t]{2}{*}{ G17 } & Mekanisme untuk saran dan masalah etika & 0,18 & 0,60 \\
\hline & Sub jumlah & 0,09 & 0,04 \\
\hline \multicolumn{4}{|c|}{ TATA KELOLA (GOVERNANCE) } \\
\hline G18 & Struktur tata kelola & 1,00 & 0,78 \\
\hline G19 & Mendelegasikan wewenang & 0,36 & 0,52 \\
\hline G20 & $\begin{array}{l}\text { Tanggung jawab tingkat eksekutif untuk topik ekonomi, } \\
\text { lingkungan, dan sosial }\end{array}$ & 0,00 & 0,30 \\
\hline G21 & $\begin{array}{l}\text { Berkonsultasi dengan para pemangku kepentingan } \\
\text { mengenai topik-topik ekonomi, lingkungan, dan sosial }\end{array}$ & 0,00 & 0,32 \\
\hline G22 & Komposisi badan tata kelola tertinggi dan komitenya & 0,64 & 0,48 \\
\hline G23 & Ketua badan tata kelola tertinggi & 0,64 & 0,48 \\
\hline
\end{tabular}




\begin{tabular}{|c|c|c|c|}
\hline G24 & Menominasikan dan memilih badan tata kelola tertinggi & 0,64 & 0,42 \\
\hline G25 & Konflik kepentingan & 0,36 & 0,38 \\
\hline G26 & $\begin{array}{l}\text { Peran badan tata kelola tertinggi dalam menetapkan } \\
\text { tujuan, nilai-nilai, dan strategi }\end{array}$ & 0,00 & 0,40 \\
\hline G27 & Pengetahuan kolektif badan tata kelola tertinggi & 0,00 & 0,20 \\
\hline G28 & Mengevaluasi kinerja badan tata kelola tertinggi & 0,36 & 0,48 \\
\hline G29 & $\begin{array}{l}\text { Mengidentifikasi \& mengelola dampak ekonomi, } \\
\text { lingkungan, dan sosial }\end{array}$ & 0,00 & 0,18 \\
\hline G30 & Keefektifan proses manajemen risiko & 0,64 & 0,60 \\
\hline G31 & Pengkajian topik ekonomi, lingkungan, dan sosial & 0,00 & 0,30 \\
\hline G32 & $\begin{array}{l}\text { Peran badan tata kelola tertinggi dalam pelaporan } \\
\text { keberlanjutan }\end{array}$ & 0,00 & 0,26 \\
\hline G33 & Mengomunikasikan hal-hal kritis & 0,00 & 0,30 \\
\hline G34 & Sifat dan jumlah total hal-hal kritis & 0,00 & 0,14 \\
\hline G35 & Kebijakan remunerasi & 0,64 & 0,46 \\
\hline G36 & Proses untuk menentukan remunerasi & 0,64 & 0,44 \\
\hline G37 & $\begin{array}{l}\text { Keterlibatan para pemangku kepentingan dalam } \\
\text { remunerasi }\end{array}$ & 0,09 & 0,16 \\
\hline G38 & Rasio kompensasi total tahunan & 0,64 & 0,24 \\
\hline G39 & $\begin{array}{l}\text { Persentase kenaikan pada total rasio kompensasi total } \\
\text { tahunan }\end{array}$ & 0,64 & 0,24 \\
\hline & Sub jumlah & 7,27 & 8,12 \\
\hline \multicolumn{4}{|c|}{$\begin{array}{l}\text { KETERLIBATAN PEMANGKU KEPENTINGAN (STAKEHOLDER } \\
\text { ENGAGEMENT) }\end{array}$} \\
\hline G40 & Daftar kelompok pemangku kepentingan & 0,36 & 0,30 \\
\hline G41 & Perjanjian perundingan kolektif & 0,27 & 0,26 \\
\hline G42 & Mengidentifikasi dan memilih pemangku kepentingan & 0,36 & 0,44 \\
\hline G43 & Pendekatan untuk keterlibatan pemangku kepentingan & 0,55 & 0,44 \\
\hline \multirow[t]{2}{*}{ G44 } & Topik utama dan hal-hal yang diajukan & 0,55 & 0,30 \\
\hline & Sub jumlah & 2,09 & 1,74 \\
\hline \multicolumn{4}{|c|}{ PRAKTIK LAPORAN (REPORT PRACTICE) } \\
\hline G45 & $\begin{array}{l}\text { Entitas yang termasuk dalam laporan keuangan } \\
\text { dikonsolidasi }\end{array}$ & 0,55 & 0,62 \\
\hline G46 & Menetapkan isi laporan dan Batasan topik & 0,36 & 0,38 \\
\hline G47 & Daftar topik material & 0,45 & 0,34 \\
\hline G48 & Penyajian kembali informasi & 0,36 & 0,26 \\
\hline G49 & Perubahan dalam pelaporan & 0,55 & 0,34 \\
\hline G50 & Periode pelaporan & 0,64 & 0,50 \\
\hline G51 & Tanggal laporan terbaru & 0,64 & 0,42 \\
\hline G52 & Siklus pelaporan & 0,64 & 0,46 \\
\hline G53 & Titik kontak untuk pertanyaan mengenai laporan & 0,73 & 0,44 \\
\hline G54 & Mengklaim pelaporan sesuai dengan Standar GRI & 0,36 & 0,26 \\
\hline G55 & Indeks isi GRI & 0,36 & 0,28 \\
\hline \multirow[t]{4}{*}{ G56 } & Assurance/jaminan oleh pihak eksternal & 0,36 & 0,36 \\
\hline & Sub jumlah & 6,00 & 4,62 \\
\hline & Jumlah nilai rata-rata Standar Pengungkapan Umum (A) & 28,82 & 25,76 \\
\hline & Nilai indeks rata-rata Standar Pengungkapan Umum (A : 56) & 0,51 & 0,46 \\
\hline
\end{tabular}




\begin{tabular}{|c|c|c|c|}
\hline \multicolumn{4}{|c|}{$\begin{array}{l}\text { PENGUNGKAPAN EKONOMI (ECONOMIC) } \\
\text { KINERJA EKONOMI (ECONOMIC PERFORMANCE) }\end{array}$} \\
\hline EC1 & Pendekatan manajemen & 0,36 & 0,52 \\
\hline EC2 & $\begin{array}{l}\text { Nilai ekonomi langsung yang dihasilkan dan } \\
\text { didistribusikan }\end{array}$ & 0,45 & 0,40 \\
\hline \multirow[t]{2}{*}{ EC3 } & $\begin{array}{l}\text { Kewajiban program pensiun manfaat pasti dan program } \\
\text { pensiun lainnya }\end{array}$ & 0,73 & 0,32 \\
\hline & Sub jumlah & 1,55 & 1,24 \\
\hline \multicolumn{4}{|c|}{ KEBERADAAN PASAR (MARKET PRESENCE) } \\
\hline EC4 & Pendekatan manajemen & 0,09 & 0,38 \\
\hline EC5 & $\begin{array}{l}\text { Rasio standar upah karyawan entry-level berdasarkan jenis } \\
\text { kelamin terhadap upah minimum regional }\end{array}$ & 0,36 & 0,24 \\
\hline \multirow[t]{2}{*}{ EC6 } & $\begin{array}{l}\text { Proporsi manajemen senior yang berasal dari masyarakat } \\
\text { lokal }\end{array}$ & 0,09 & 0,22 \\
\hline & Sub jumlah & 0,55 & 0,84 \\
\hline \multicolumn{4}{|c|}{$\begin{array}{l}\text { DAMPAK EKONOMI TIDAK LANGSUNG (INDIRECT ECONOMIC } \\
\text { IMPACTS) }\end{array}$} \\
\hline EC7 & Pendekatan manajemen & 0,36 & 0,36 \\
\hline EC8 & Investasi infrastruktur dan dukungan layanan & 0,36 & 0,40 \\
\hline \multirow[t]{2}{*}{ EC9 } & Dampak ekonomi tidak langsung yang signifikan & 0,18 & 0,22 \\
\hline & Sub jumlah & 0,91 & 0,98 \\
\hline \multicolumn{4}{|c|}{ PRAKTIK PENGADAAN (PROCUREMENT PRACTICES) } \\
\hline EC10 & Pendekatan manajemen & 0,09 & 0,16 \\
\hline \multirow[t]{2}{*}{ EC11 } & Proporsi pengeluaran untuk pemasok lokal & 0,00 & 0,12 \\
\hline & Sub jumlah & 0,09 & 0,28 \\
\hline \multicolumn{4}{|c|}{ ANTI KORUPSI (ANTI CCORUPTION) } \\
\hline EC12 & Pendekatan manajemen & 0,36 & 0,50 \\
\hline EC13 & Operasi-operasi yang dinilai memiliki risiko terkait korupsi & 0,27 & 0,44 \\
\hline EC14 & $\begin{array}{l}\text { Komunikasi dan pelatihan tentang kebijakan dan prosedur } \\
\text { anti-korupsi }\end{array}$ & 0,36 & 0,42 \\
\hline \multirow[t]{2}{*}{ EC15 } & Insiden korupsi yang terbukti dan tindakan yang diambil & 0,36 & 0,28 \\
\hline & Sub jumlah & 1,36 & 1,64 \\
\hline \multicolumn{4}{|c|}{ PERILAKU ANTI PERSAINGAN (ANTI COMPETITIVE BEHAVIOR) } \\
\hline EC16 & Pendekatan manajemen & 0,09 & 0,08 \\
\hline \multirow[t]{4}{*}{ EC17 } & $\begin{array}{l}\text { Langkah-langkah hukum untuk perilaku anti-persaingan, } \\
\text { praktik anti-trust dan monopoli }\end{array}$ & 0,00 & 0,04 \\
\hline & Sub jumlah & 0,09 & 0,12 \\
\hline & Jumlah nilai rata-rata Standar Pengungkapan Ekonomi (B) & 4,55 & 5,10 \\
\hline & ilai indeks rata-rata Standar Pengungkapan Ekonomi (B : 17) & 0,27 & 0,30 \\
\hline \multicolumn{4}{|c|}{ PENGUNGKAPAN LINGKUNGAN (ENVIRONMENT) } \\
\hline EN1 & Pendekatan manajemen & 0,27 & 0,12 \\
\hline EN2 & Material yang digunakan berdasarkan berat atau volume & 0,18 & 0,12 \\
\hline EN3 & Material input dari daur ulang yang digunakan & 0,00 & 0,02 \\
\hline \multirow[t]{2}{*}{ EN4 } & $\begin{array}{l}\text { Produk reclaimed (diolah kembali) dan material } \\
\text { kemasannya }\end{array}$ & 0,00 & 0,02 \\
\hline & Sub jumlah & 0,45 & 0,28 \\
\hline
\end{tabular}




\begin{tabular}{|c|c|c|c|}
\hline \multicolumn{4}{|c|}{ ENERGI } \\
\hline EN5 & Pendekatan manajemen & 0,27 & 0,16 \\
\hline EN6 & Konsumsi energi dalam organisasi & 0,18 & 0,16 \\
\hline EN7 & Konsumsi energi di luar organisasi & 0,00 & 0,04 \\
\hline EN8 & Intensitas energi & 0,09 & 0,10 \\
\hline EN9 & Pengurangan konsumsi energi & 0,27 & 0,20 \\
\hline \multirow[t]{2}{*}{ EN10 } & $\begin{array}{l}\text { Pengurangan pada energi yang dibutuhkan untuk produk } \\
\text { dan jasa }\end{array}$ & 0,00 & 0,22 \\
\hline & Sub jumlah & 0,82 & 0,88 \\
\hline \multicolumn{4}{|c|}{ AIR (WATER) } \\
\hline EN11 & Pendekatan manajemen & 0,18 & 0,16 \\
\hline EN12 & Pengambilan air berdasarkan sumber & 0,09 & 0,10 \\
\hline EN13 & $\begin{array}{l}\text { Sumber air yang secara signifikan dipengaruhi oleh } \\
\text { pengambilan air }\end{array}$ & 0,00 & 0,02 \\
\hline \multirow[t]{2}{*}{ EN14 } & Daur ulang dan penggunaan air kembali & 0,00 & 0,08 \\
\hline & Sub jumlah & 0,27 & 0,36 \\
\hline \multicolumn{4}{|c|}{ KEANEKARAGAMAN HAYATI (BIODIVERSITY) } \\
\hline EN15 & Pendekatan manajemen & 0,18 & 0,02 \\
\hline EN16 & $\begin{array}{l}\text { Lokasi operasi yang dimiliki, disewa, dikelola, atau } \\
\text { berdekatan dengan, kawasan lindung dan kawasan dengan } \\
\text { nilai keanekaragaman hayati tinggi di luar kawasan } \\
\text { lindung }\end{array}$ & 0,00 & 0,02 \\
\hline \multirow[t]{2}{*}{ EN17 } & $\begin{array}{l}\text { Dampak signifikan dari kegiatan, produk, dan jasa pada } \\
\text { keanekaragaman hayati }\end{array}$ & 0,09 & 0,02 \\
\hline & Sub jumlah & 0,27 & 0,06 \\
\hline \multicolumn{4}{|c|}{ EMISI (EMISSION) } \\
\hline EN18 & Pendekatan manajemen & 0,18 & 0,02 \\
\hline EN19 & Emisi GRK (Gas Rumah Kaca) & 0,09 & 0,04 \\
\hline \multirow[t]{2}{*}{ EN20 } & Pengurangan emisi GRK & 0,09 & 0,06 \\
\hline & Sub jumlah & 0,36 & 0,12 \\
\hline \multicolumn{4}{|c|}{ AIR LIMBAH DAN LIMBAH (EFFLUENTS AND WASTE) } \\
\hline EN21 & Pendekatan manajemen & 0,18 & 0,06 \\
\hline EN22 & Pelepasan air berdasarkan mutu dan tujuan & 0,00 & 0,06 \\
\hline EN23 & Limbah berdasarkan jenis dan metode pembuangan & 0,09 & 0,14 \\
\hline \multirow[t]{2}{*}{ EN24 } & Tumpahan yang signifikan & 0,09 & 0,04 \\
\hline & Sub jumlah & 0,36 & 0,30 \\
\hline \multicolumn{4}{|c|}{ KEPATUHAN LINGKUNGAN (ENVIRONMENTAL COMPLIANCE) } \\
\hline EN25 & Pendekatan manajemen & 0,09 & 0,12 \\
\hline \multirow[t]{2}{*}{ EN26 } & $\begin{array}{l}\text { Kepatuhan terhadap undang-undang dan peraturan } \\
\text { tentang lingkungan hidup }\end{array}$ & 0,00 & 0,08 \\
\hline & Sub jumlah & 0,09 & 0,20 \\
\hline \multicolumn{4}{|c|}{$\begin{array}{l}\text { PENILAIAN LINGKUNGAN PEMASOK (SUPPLIER } \\
\text { ENVIRONMENTAL ASSESSMENT) }\end{array}$} \\
\hline EN27 & Pendekatan manajemen & 0,09 & 0,02 \\
\hline EN28 & $\begin{array}{l}\text { Seleksi pemasok baru dengan menggunakan kriteria } \\
\text { lingkungan }\end{array}$ & 0,00 & 0,00 \\
\hline EN29 & $\begin{array}{l}\text { Dampak lingkungan negatif dalam rantai pasokan dan } \\
\text { tindakan yang telah diambil }\end{array}$ & 0,00 & 0,02 \\
\hline
\end{tabular}




\begin{tabular}{|c|c|c|c|}
\hline & Sub jumlah & 0,09 & 0,04 \\
\hline & umlah nilai rata-rata Standar Pengungkapan Lingkungan (C) & 2,73 & 2,24 \\
\hline Nila & indeks rata-rata Standar Pengungkapan Lingkungan (C:29) & 0,09 & 0,08 \\
\hline PENGU & GKAPAN SOSIAL (SOCIAL) & & \\
\hline KEPEGA & NAIAN (EMPLOYMENT) & & \\
\hline SOC1 & Pendekatan manajemen untuk kepegawaian & 0,09 & 0,28 \\
\hline SOC2 & Perekrutan karyawan baru dan pergantian karyawan & 0,82 & 0,44 \\
\hline SOC3 & $\begin{array}{l}\text { Tunjangan yang diberikan kepada karyawan purnawaktu } \\
\text { yang tidak diberikan kepada karyawan sementara atau } \\
\text { paruh waktu }\end{array}$ & 0,27 & 0,30 \\
\hline SOC4 & Cuti melahirkan & 0,18 & 0,20 \\
\hline & Sub jumlah & 1,36 & 1,22 \\
\hline $\begin{array}{l}\text { HUBUN } \\
\text { MANAC }\end{array}$ & $\begin{array}{l}\text { AN TENAGA KERJA-MANAJEMEN (LABOR } \\
\text { MENT RELATION) }\end{array}$ & & \\
\hline SOC5 & Pendekatan manajemen untuk hubungan tenaga kerja & 0,00 & 0,12 \\
\hline SOC6 & $\begin{array}{l}\text { Periode pemberitahuan minimum terkait perubahan } \\
\text { operasional }\end{array}$ & 0,00 & 0,08 \\
\hline & Sub jumlah & 0,00 & 0,20 \\
\hline $\begin{array}{l}\text { KESEH } \\
\text { HEALTH }\end{array}$ & $\begin{array}{l}\text { ГAN DAN KESELAMATAN KERJA (OCCUPATIONAL- } \\
\text { AND-SAFETY) }\end{array}$ & & \\
\hline SOC7 & $\begin{array}{l}\text { Pendekatan manajemen untuk kesehatan dan keselamatan } \\
\text { kerja }\end{array}$ & 0,27 & 0,22 \\
\hline SOC8 & $\begin{array}{l}\text { Perwakilan pekerja dalam komite resmi gabungan } \\
\text { manajemen pekerja untuk kesehatan dan keselamatan } \\
\text { Jenis kecelakaan keria dan tingkat kecelakaan keria. }\end{array}$ & 0,45 & 0,30 \\
\hline SOC9 & $\begin{array}{l}\text { penyakit akibat kerja, hari kerja yang hilang, dan } \\
\text { ketidakhadiran, serta jumlah kematian terkait pekerjaan }\end{array}$ & 0,18 & 0,26 \\
\hline SOC10 & $\begin{array}{l}\text { Para pekerja dengan risiko kecelakaan atau penyakit } \\
\text { berbahaya tinggi terkait dengan pekerjaan mereka }\end{array}$ & 0,36 & 0,28 \\
\hline SOC11 & $\begin{array}{l}\text { Topik kesehatan dan keselamatan yang tercakup dalam } \\
\text { perjanjian resmi dengan serikat buruh }\end{array}$ & 0,45 & 0,24 \\
\hline & Sub jumlah & 1,73 & 1,30 \\
\hline PELATI & AN DAN PENDIDIKAN (TRAINING AND EDUCATION) & & \\
\hline SOC12 & Pendekatan manajemen untuk pelatihan dan pendidikan & 0,27 & 0,34 \\
\hline SOC13 & Rata-rata jam pelatihan per tahun per karyawan & 1,00 & 0,44 \\
\hline SOC14 & $\begin{array}{l}\text { Program untuk meningkatkan keterampilan karyawan dan } \\
\text { program bantuan peralihan }\end{array}$ & 1,00 & 0,46 \\
\hline SOC15 & $\begin{array}{l}\text { Persentase karyawan yang menerima tinjauan rutin } \\
\text { terhadap kinerja dan pengembangan karier }\end{array}$ & 0,73 & 0,36 \\
\hline & Sub jumlah & 3,00 & 1,60 \\
\hline $\begin{array}{l}\text { KEANE } \\
(D I V E R\end{array}$ & $\begin{array}{l}\text { ARAGAMAN DAN KESETARAAN KESEMPATAN } \\
\text { TY AND EQUAL OPPORTUNITY) }\end{array}$ & & \\
\hline SOC16 & $\begin{array}{l}\text { Pendekatan manajemen untuk keanekaragaman dan } \\
\text { kesetaraan kesempatan }\end{array}$ & 0,00 & 0,12 \\
\hline SOC17 & Keanekaragaman badan tata kelola dan karyawan & 0,00 & 0,16 \\
\hline SOC18 & $\begin{array}{l}\text { Rasio gaji pokok dan remunerasi perempuan dibandingkan } \\
\text { laki-laki }\end{array}$ & 0,73 & 0,38 \\
\hline & Sub jumlah & 0,73 & 0,66 \\
\hline
\end{tabular}




\begin{tabular}{|c|c|c|c|}
\hline \multicolumn{4}{|c|}{ NON DISKRIMINASI (NON DISCRIMINATION) } \\
\hline SOC19 & \multirow{2}{*}{$\begin{array}{l}\text { Pendekatan manajemen untuk non diskriminasi } \\
\text { Insiden diskriminasi dan tindakan perbaikan yang } \\
\text { dilakukan }\end{array}$} & 0,00 & 0,06 \\
\hline \multirow[t]{2}{*}{ SOC20 } & & 0,09 & 0,08 \\
\hline & Sub jumlah & 0,09 & 0,14 \\
\hline \multicolumn{4}{|c|}{$\begin{array}{l}\text { KEBEBASAN BERSERIKAT DAN PERUNDINGAN KOLEKTIF } \\
\text { (FREEDOM OF ASSOCIATION AND COLLECTIVE BARGAINING) }\end{array}$} \\
\hline \multirow{3}{*}{$\begin{array}{l}\text { SOC21 } \\
\text { SOC22 }\end{array}$} & $\begin{array}{l}\text { Pendekatan manajemen untuk kebebasan berserikat dan } \\
\text { perundingan kolektif }\end{array}$ & 0,18 & 0,02 \\
\hline & $\begin{array}{l}\text { Operasi dan pemasok di mana hak atas kebebasan } \\
\text { berserikat dan perundingan kolektif mungkin berisiko }\end{array}$ & 0,36 & 0,06 \\
\hline & Sub jumlah & 0,55 & 0,08 \\
\hline \multicolumn{4}{|c|}{ PEKERJA ANAK (CHILD LABOR) } \\
\hline SOC23 & \multirow{2}{*}{$\begin{array}{l}\text { Pendekatan manajemen untuk pekerja anak } \\
\text { Operasi dan pemasok yang berisiko signifikan terhadap } \\
\text { insiden pekerja anak }\end{array}$} & 0,09 & 0,04 \\
\hline \multirow[t]{2}{*}{$\mathrm{SOC} 24$} & & 0,09 & 0,04 \\
\hline & Sub jumlah & 0,18 & 0,08 \\
\hline \multicolumn{4}{|c|}{$\begin{array}{l}\text { KERJA PAKSA ATAU WAJIB KERJA (FORCED OF COMPULSORY } \\
L A B O R)\end{array}$} \\
\hline SOC25 & \multirow{2}{*}{$\begin{array}{l}\text { Pendekatan manajemen untutk kerja paksa atau wajib kerja } \\
\text { Operasi dan pemasok yang berisiko signifikan terhadap } \\
\text { insiden kerja paksa atau wajib kerja }\end{array}$} & 0,09 & 0,04 \\
\hline \multirow[t]{2}{*}{ SOC26 } & & 0,09 & 0,04 \\
\hline & Sub jumlah & 0,18 & 0,08 \\
\hline \multicolumn{4}{|c|}{ PRAKTIK KEAMANAN (SECURITY PRACTICES) } \\
\hline SOC27 & \multirow{2}{*}{$\begin{array}{l}\text { Pendekatan manajemen untuk praktik keamanan } \\
\text { Petugas keamanan yang dilatih mengenai kebijakan atau } \\
\text { prosedur hak asasi manusia }\end{array}$} & 0,00 & 0,06 \\
\hline \multirow[t]{2}{*}{ SOC28 } & & 0,18 & 0,18 \\
\hline & Sub jumlah & 0,18 & 0,24 \\
\hline \multicolumn{4}{|c|}{$\begin{array}{l}\text { HAK-HAK MASYARAKAT ADAT (RIGHTS OF INDIGENOUS } \\
\text { PEOPLES) }\end{array}$} \\
\hline SOC29 & \multirow{2}{*}{$\begin{array}{l}\text { Pendekatan manajemen untuk hak-hak masyarakat adat } \\
\text { Insiden pelanggaran yang melibatkan hak-hak masyarakat } \\
\text { adat }\end{array}$} & 0,00 & 0,02 \\
\hline \multirow[t]{2}{*}{$\mathrm{SOC} 30$} & & 0,00 & 0,02 \\
\hline & Sub jumlah & 0,00 & 0,04 \\
\hline \multicolumn{4}{|c|}{$\begin{array}{l}\text { PENILAIAN HAK ASASI MANUSIA (HUMAN RIGHTS } \\
\text { ASSESSMENT) }\end{array}$} \\
\hline SOC31 & Pendekatan manajemen untuk penilaian hak asasi manusia & 0,00 & 0,06 \\
\hline SOC32 & $\begin{array}{l}\text { Operasi-operasi yang telah melewati tinjauan hak asasi } \\
\text { manusia atau penilaian dampak }\end{array}$ & 0,09 & 0,02 \\
\hline SOC33 & $\begin{array}{l}\text { Pelatihan karyawan mengenai kebijakan atau prosedur hak } \\
\text { asasi manusia }\end{array}$ & 0,00 & 0,00 \\
\hline \multirow[t]{2}{*}{ SOC34 } & $\begin{array}{l}\text { Perjanjian dan kontrak investasi signifikan yang } \\
\text { memasukkan klausul-klausul hak asasi manusia atau yang } \\
\text { telah melalui penyaringan hak asasi manusi }\end{array}$ & 0,00 & 0,00 \\
\hline & Sub jumlah & 0,09 & 0,08 \\
\hline \multicolumn{4}{|c|}{ MASYARAKAT LOKAL (LOCAL COMMUNITIES) } \\
\hline SOC35 & Pendekatan manajemen untuk masyarakat lokal & 0,09 & 0,10 \\
\hline
\end{tabular}




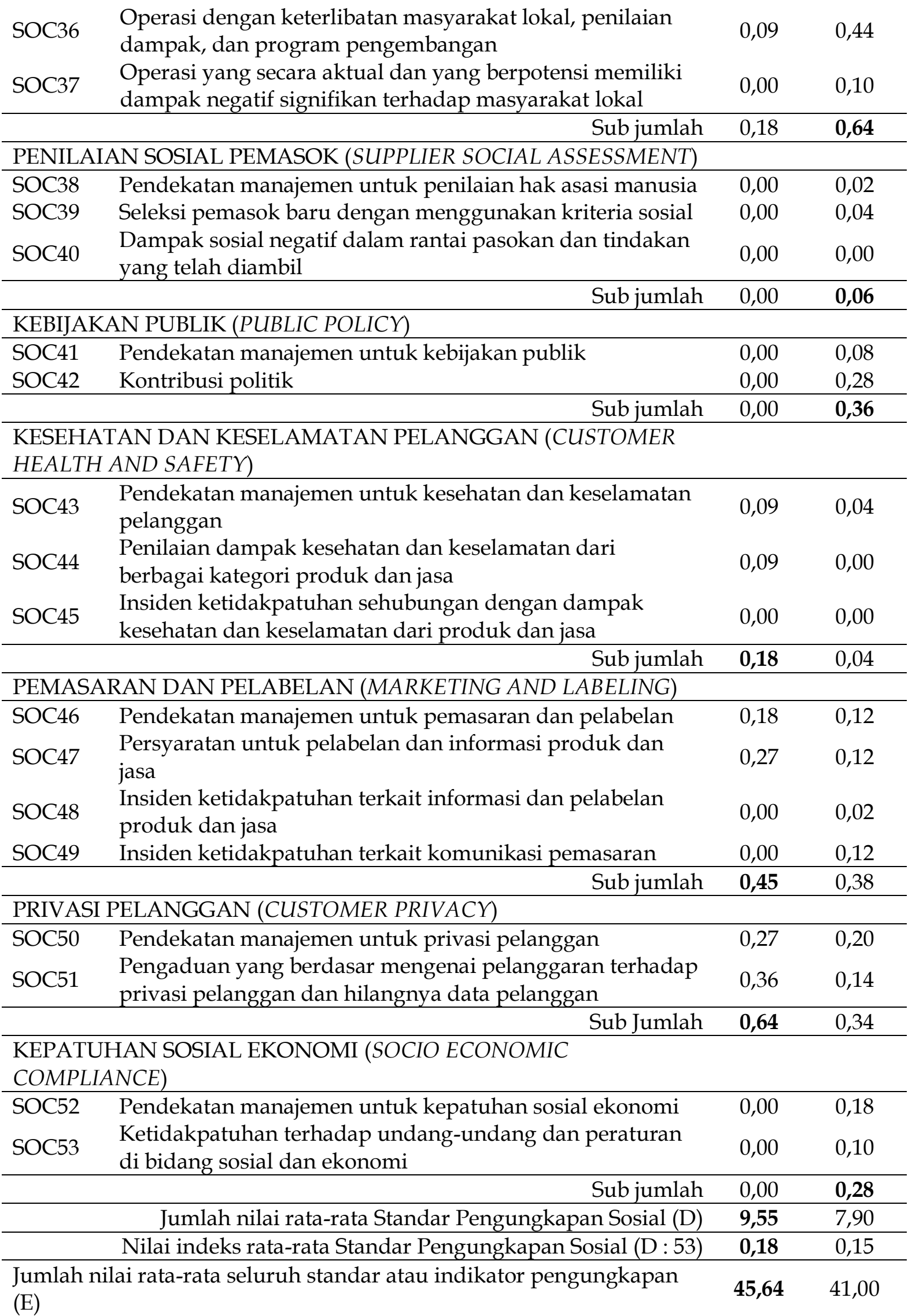




\begin{tabular}{lcc}
\hline $\begin{array}{l}\text { Jumlah nilai rata-rata ideal (seluruh standar atau indikator } \\
\text { diungkapkan) (F) }\end{array}$ & 155,00 & 155,00 \\
\hline Nilai indeks rata-rata Pengungkapan TJSL (E : F) & $\mathbf{0 , 2 9 4}$ & 0264 \\
\hline
\end{tabular}

Sumber: Data hasil penelitian, diolah (2019)

Tabel 3 menunjukkan nilai indeks ratarata pengungkapan TJSL pada bank syariah adalah sebesar 0,294 atau $29,4 \%$ yang lebih tinggi dibandingkan nilai indeks rata-rata pada bank konvensional sebesar 0,264 atau $26,4 \%$. Terlihat pula bahwa bank syariah memiliki keunggulan pengungkapan TJSL pada tiga dari empat standar pengungkapan yaitu standar pengungkapan umum, standar pengungkapan lingkungan, dan standar pengungkapan sosial. Pada standar pengungkapan umum, bank syariah memiliki nilai indeks rata-rata 0,51 dibandingkan bank konvensional 0,46. Pada standar pengungkapan lingkungan, bank syariah memiliki nilai indeks rata-rata 0,09 dibandingkan bank konvensional 0,08. Sedangkan pada standar pengungkapan sosial, bank syariah memiliki nilai indeks rata-rata 0,18 dibandingkan bank konvensional 0,015. Ini menunjukkan bahwa bank syariah memberikan perhatian yang besar pada standar pengungkapan umum terutama pada substandar profil organisasi substandar etika dan integritas, substandar keterlibatan pemangku kepentingan, dan substandar praktik pelaporan. Bank syariah juga memberikan perhatian pada standar pengungkapan lingkungan terutama pada substandar material, substandar keanekaragaman hayati, substandar emisi, substandar air limbah dan limbah, dan substandar penilaian lingkungan pemasok. Demikian juga halnya dengan standar pengungkapan sosial terutama pada substandar kepegawaian, substandar kesehatan dan keselamatan kerja, substandar pelatihan dan pendidikan, substandar keanekaragaman dan kesetaraan kesempatan, substandar kebebasan berserikat dan perundingan kolektif, substandar pekerja anak, substandar kerja paksa atau wajib kerja, substandar penilaian hak asasi manusia, substandar kesehatan dan keselamatan pelanggan, substandar pemasaran dan pelabelan, serta substandar privasi pelanggan. Walaupun secara keseluruhan pengungkapan TJSL bank syariah lebih unggul, namun bank konvensional lebih unggul pada satu standar pengungkapan yaitu standar pengungkapan ekonomi. Pada standar ini, nilai indeks rata-rata bank konvensional adalah 0,30 dibandingkan bank syariah 0,27. Keunggulan ini berasal dari substandar keberadaan pasar, substandar dampak ekonomi tidak langsung, substandar praktik pengadaan, substandar anti korupsi, dan substandar perilaku anti persaingan.

\section{Analisis Regresi Berganda}

Analisis regresi berganda berguna untuk menghasilkan suatu model untuk memprediksi nilai variabel dependen $(\mathrm{Y})$ berdasarkan perubahan yang terjadi pada variabel independen $(X)$. Analisis regresi menunjukkan hasil sebagaimana disajikan pada Tabel 4. Berdasarkan hasil tersebut, dapat dibentuk model persamaan regresi sebagai berikut:

$Y=0,264+2,367 / 10$ Kuadriliun $_{1}-1,566 X_{2}-$

$0,011 X_{3}-0,192 X_{4}+0,014 X_{5}+\varepsilon$

Dari model persamaan regresi yang dihasilkan, terlihat bahwa pengungkapan TJSL dapat diprediksi oleh lima variabel independen, dengan pengaruh yang bervariasi dalam bentuk penambahan maupun pengurangan. Namun, nilai konstanta sebesar 0,264 sudah cukup besar dan mendekati nilai rata-rata pengungkapan TJSL berdasarkan hasil statistik deskriptif yaitu sebesar 0,269907. Dapat dikatakan bahwa tidak terlalu banyak kontribusi dari variabel independen karakteristik perusahaan dan elemen tata kelola perusahaan terhadap pengungkapan TJSL. Signifikansi pengaruh variabel independen terhadap variabel dependen pengungkapan TJSL akan diuraikan pada pengujian hipotesis. 
Tabel 4

Hasil Analisis Regresi Berganda

\begin{tabular}{lccccc}
\hline \hline \multirow{1}{*}{ Model } & \multicolumn{2}{c}{$\begin{array}{c}\text { Unstandardized } \\
\text { Coefficients }\end{array}$} & $\begin{array}{c}\text { Standardized } \\
\text { Coefficients }\end{array}$ & $t$ & Sig. \\
\cline { 2 - 6 } & $\boldsymbol{B}$ & Std. Error & Beta & & \\
\hline (Constant) & 0,264 & 0,087 & & 3,032 & 0,004 \\
Ukuran Perusahaan-Aset & $2.367 \mathrm{E}-16$ & 0,000 & 0,325 & 2,013 & 0,049 \\
Profitabilitas-ROA & $-1,566$ & 2,222 & $-0,276$ & $-0,705$ & 0,484 \\
Ukuran Dewan Direksi & $-0,011$ & 0,011 & $-0,178$ & $-0,982$ & 0,330 \\
Direksi Independen & $-0,192$ & 0,124 & $-0,199$ & $-1,544$ & 0,129 \\
Komite Audit & 0,014 & 0,019 & 0,115 & 0,757 & 0,452 \\
\hline
\end{tabular}

a. Dependent Variable: Pengungkapan TJSL

Sumber: Data hasil penelitian, diolah (2019)

\section{Pengujian Asumsi Klasik}

Hasil pengujian menunjukkan bahwa semua asumsi klasik telah terpenuhi. Grafik normalitas menunjukkan semua data terdistribusi secara merata di sekitar garis linear yang berarti distribusi data adalah normal dan berarti data penelitian ini memenuhi asumsi normalitas. Grafik heteroskedastisitas memperlihatkan data yang menyebar secara acak, tidak membentuk sebuah pola tertentu yang jelas, serta tersebar baik di atas maupun di bawah angka nol pada sumbu $Y$, yang berarti tidak terjadi heteroskedastisitas pada persamaan regresi sehingga model regresi layak dipergunakan untuk dasar prediksi. Hasil uji menunjukkan nilai VIF (variance inflation factor) yang lebih kecil dari 10 untuk semua variabel independen yang berarti tidak ada multikolinearitas di antara variabel independen. Hasil uji menunjukkan nilai Durbin Watson adalah 1,250 yang berada di antara -2 sampai +2 , yang berarti tidak terdapat autokorelasi.

\section{Pengujian Hipotesis Pertama (Uji Per- bedaan)}

Uji perbedaan dilakukan untuk mengetahui apakah perbedaan pengungkapan TJSL antara bank syariah dan bank konvensional signifikan atau tidak. Pengujian dilakukan dengan membandingkan nilai rata-rata pengungkapan TJSL antara kedua jenis bank dengan menggunakan uji-z. Hasil analisis perbedaan nilai rata-rata disajikan pada Tabel 5 berikut. Tabel 5 memperlihatkan nilai rata-rata pengungkapan TJSL untuk bank syariah adalah 0,294436 yang berarti rata-rata bank syariah mengungkapkan 29,44\% dari 155 indikator pengungkapan TJSL atau setara dengan 47 indikator.

Sedangkan nilai rata-rata pengungkapan TJSL untuk bank konvensional adalah 0,264510 yang berarti rata-rata bank konvensional mengungkapkan $26,45 \%$ dari 155 indikator pengungkapan TJSL atau setara dengan 41 indikator. Karena nilai rata-rata pada kedua jenis bank lebih besar daripada nilai standar deviasi maka berarti data variabel pengungkapan TJSL relatif sama atau tidak terlalu bervariasi.

Hasil ini sama dengan hasil perhitungan pengungkapan TJSL sebelumnya yang disajikan pada Tabel 5 yaitu sebesar 0,294 untuk bank syariah dan 0,264 untuk bank konvensional. Selanjutnya dilakukan pengujian signifikansi perbedaan (pengujian hipotesis pertama) yang hasilnya ditunjukkan oleh Tabel 6.

Hipotesis pertama:

$\mathrm{H}_{01}: \mu_{\mathrm{BS}}=\mu_{\mathrm{BK}}$ Tidak ada perbedaan pengungkapan TJSL pada bank syariah dan bank konvensional.

$\mathrm{H}_{\mathrm{a} 1}: \mu_{\mathrm{BS}} \neq \mu_{\mathrm{BK}}$ Ada perbedaan pengungkapan TJSL pada bank syariah dan bank konvensional. 
Tabel 5

Hasil Analisis Perbedaan Nilai Rata-rata

\begin{tabular}{clccc}
\hline \hline & \multicolumn{1}{c}{ Jenis Bank } & N & Rata-rata & $\begin{array}{c}\text { Standar } \\
\text { Deviasi }\end{array}$ \\
\hline \multirow{2}{*}{ Pengungkapan TJSL } & Bank Syariah & 11 & 0,294436 & 0,0890697 \\
\cline { 2 - 5 } & Bank Konvensional & 50 & 0,264510 & 0,1500468 \\
\hline
\end{tabular}

Sumber: Data hasil penelitian, diolah (2019)

Tabel 6 menunjukkan nilai $\mathrm{t}$ yang dihasilkan dalam uji-z adalah sebesar 0,874 dengan signifikansi untuk uji 2 sisi sebesar $0,390 / 2=0,195$. Karena nilai signifikansi 0,195 > 0,025 (yaitu nilai error atau $\alpha$ sebesar
0,05 dibagi 2), maka $\mathrm{H}_{01}$ diterima dan $\mathrm{H}_{\mathrm{a} 1}$ ditolak.

Ini berarti tidak ada perbedaan pengungkapan TJSL antara bank syariah dan bank konvensional.

Tabel 6

Hasil Uji Signifikansi Perbedaan Nilai Rata-rata

\begin{tabular}{lcccc}
\hline \hline & \multicolumn{3}{c}{$z$-test for Equality of Means } \\
\cline { 2 - 4 } & & $\boldsymbol{t}$ & $\boldsymbol{d f}$ & Sig. (2-tailed) \\
\hline Pengungkapan TJSL & Equal variances not assumed & 0,874 & 24,440 & 0,390 \\
\hline Sumber: Data hasil penelitian, diolah (2019) & & &
\end{tabular}

Pengujian Hipotesis Kedua sampai dengan Hipotesis Keenam (Uji Signifikansi Pengaruh)

Pengujian hipotesis kedua sampai dengan hipotesis keenam dilakukan dengan merujuk pada hasil analisis regresi berganda yang telah disajikan pada Tabel 4 .

Hipotesis kedua:

$\mathrm{H}_{02}: \beta_{1}=0$ Karakteristik perusahaan berupa ukuran perusahaan tidak berpengaruh terhadap pengungkapan TJSL pada bank syariah dan bank konvensional.

$\mathrm{H}_{\mathrm{a} 2}: \beta_{1}>0$ Karakteristik perusahaan berupa ukuran perusahaan berpengaruh positif terhadap pengungkapan TJSL pada bank syariah dan bank konvensional.

Untuk variabel karakteristik perusahaan berupa ukuran perusahaan (aset), pada Tabel 4 terlihat nilai signifikansi sebesar 0,049 yang lebih kecil dari $\alpha$ sebesar 0,050. Dengan demikian maka $\mathrm{H}_{02}$ ditolak dan $\mathrm{H}_{\mathrm{a} 2}$ diterima, yang berarti ukuran perusahaan (aset) berpengaruh positif terhadap pengungkapan TJSL pada bank syariah dan bank konvensional. Dengan kata lain, semakin besar ukuran perusahaan yang dilihat dari banyaknya aset, maka semakin banyak pula pengungkapan TJSL yang dilakukan.

Hipotesis ketiga:

$\mathrm{H}_{03}: \beta_{2}=0$ Karakteristik perusahaan berupa profitabilitas tidak berpengaruh terhadap pengungkapan TJSL pada bank syariah dan bank konvensional.

$\mathrm{H}_{\mathrm{a} 3}: \beta_{2}>0$ Karakteristik perusahaan berupa profitabilitas berpengaruh positif terhadap pengungkapan TJSL pada bank syariah dan bank konvensional.

Untuk variabel karakteristik perusahaan berupa profitabilitas (ROA), pada Tabel 4 terlihat nilai signifikansi sebesar 0,484 yang lebih besar dari $\alpha$ sebesar 0,050. Dengan demikian maka $\mathrm{H}_{03}$ diterima dan $\mathrm{H}_{\mathrm{a} 3}$ ditolak, yang berarti profitabilitas (ROA) tidak berpengaruh terhadap pengungkapan TJSL pada bank syariah dan bank konvensional. Hipotesis keempat:

$\mathrm{H}_{04}: \beta_{3}=0$ Elemen tata kelola perusahaan berupa ukuran dewan direksi 
tidak berpengaruh terhadap pengungkapan TJSL pada bank syariah dan bank konvensional.

$\mathrm{H}_{\mathrm{a} 4}: \beta_{3}>0$ Elemen tata kelola perusahaan berupa ukuran dewan direksi berpengaruh positif terhadap pengungkapan TJSL pada bank syariah dan bank konvensional.

Untuk variabel elemen tata kelola perusahaan berupa ukuran dewan direksi, pada Tabel 4 terlihat nilai signifikansi sebesar 0,330 yang lebih besar dari $\alpha$ sebesar 0,050. Dengan demikian maka $\mathrm{H}_{04}$ diterima dan $\mathrm{H}_{\mathrm{a} 4}$ ditolak, yang berarti ukuran dewan direksi tidak berpengaruh terhadap pengungkapan TJSL pada bank syariah dan bank konvensional.

Hipotesis kelima:

$\mathrm{H}_{05}: \beta_{4}=0$ Elemen tata kelola perusahaan berupa direksi independen tidak berpengaruh terhadap pengungkapan TJSL pada bank syariah dan bank konvensional.

$\mathrm{H}_{\mathrm{a} 5}: \beta_{4}>0$ Elemen tata kelola perusahaan berupa direksi independen berpengaruh positif terhadap pengungkapan TJSL pada bank syariah dan bank konvensional.

Untuk variabel elemen tata kelola perusahaan berupa direksi independen, pada Tabel 4 terlihat nilai signifikansi sebesar 0,129 yang lebih besar dari $\alpha$ sebesar 0,050. Dengan demikian maka $\mathrm{H}_{05}$ diterima dan $\mathrm{H}_{\mathrm{a} 5}$ ditolak, yang berarti direksi independen tidak berpengaruh terhadap pengungkapan TJSL pada bank syariah dan bank konvensional.

Hipotesis keenam:

$\mathrm{H}_{06}: \beta_{5}=0$ Elemen tata kelola perusahaan berupa komite audit tidak berpengaruh terhadap pengungkapan TJSL pada bank syariah dan bank konvensional.

$\mathrm{H}_{\mathrm{a} 6}: \beta_{5}>0$ Elemen tata kelola perusahaan berupa komite audit berpengaruh positif terhadap pengungkapan TJSL pada bank syariah dan bank konvensional.
Untuk variabel elemen tata kelola perusahaan berupa komite audit, pada Tabel 4 terlihat nilai signifikansi sebesar 0,452 yang lebih besar dari $\alpha$ sebesar 0,050. Dengan demikian maka $\mathrm{H}_{06}$ diterima dan $\mathrm{H}_{\mathrm{a} 6}$ ditolak, yang berarti komite audit tidak berpengaruh terhadap pengungkapan TJSL pada bank syariah dan bank konvensional.

\section{Pembahasan}

Hasil analisis deskriptif menunjukkan bahwa rata-rata bank syariah mengungkapkan $29,44 \%$ standar atau indikator TJSL, sedangkan rata-rata bank konvensional mengungkapkan 26,45\%. Jadi, ada perbedaan sebesar 2,99\%. Hasil pengujian statistik menunjukkan bahwa perbedaan ini tidak signifikan. Walaupun secara statistik tidak signifikan, perbedaan secara deskriptif dapat menunjukkan bahwa nilai-nilai syariah benar-benar diterapkan pada bank syariah sehingga bank syariah pada umumnya melaksanakan aktivitas TJSL serta mengungkapkannya pada laporan keberlanjutan atau laporan tahunan. Hal ini patut diapresiasi mengingat umur bank syariah yang lebih muda dibandingkan bank konvensional, jumlah bank syariah yang lebih sedikit dibandingkan bank konvensional, dan ukuran bank syariah yang lebih kecil dibandingkan bank konvensional.

Jika dilihat secara rinci, bank syariah memberikan perhatian yang besar pada standar pengungkapan umum terutama pada substandar profil organisasi, substandar etika dan integritas, substandar keterlibatan pemangku kepentingan, serta substandar praktik pelaporan. Hal ini sejalan dengan prinsip Islami yang menjunjung tinggi keterbukaan, menjaga etika dan integritas, memperhatikan relasi sosial (dengan stakeholder), serta menjalankan akuntabilitas dan transparansi (Rashid et al., 2013). Bank syariah juga memberikan perhatian pada standar pengungkapan lingkungan terutama pada substandar material, substandar keanekaragaman hayati, substandar emisi, substandar air limbah dan 
limbah, serta substandar penilaian lingkungan pemasok. Ini sangat sejalan dengan nilai dan prinsip syariah atau Islam yang mengatur bahwa manusia harus menjaga kelestarian lingkungan dan tidak membuat kerusakan di muka bumi (Aribi dan Gao, 2010). Demikian juga dengan standar pengungkapan sosial terutama pada substandar kepegawaian, substandar kesehatan dan keselamatan kerja, substandar pelatihan dan pendidikan, substandar keanekaragaman dan kesetaraan kesempatan, substandar kebebasan berserikat dan perundingan kolektif, substandar pekerja anak, substandar kerja paksa atau wajib kerja, substandar penilaian hak asasi manusia, substandar kesehatan dan keselamatan pelanggan, substandar pemasaran dan pelabelan, serta substandar privasi pelanggan. Standar pengungkapan ini terkait erat dengan ajaran Islam untuk menjaga relasi sosial (Rashid et al., 2013) dan menjalankan fardhu kifayah untuk bekerja menuju tujuan mulia seperti memerangi kemiskinan dan mengangkat orang yang kurang beruntung dan tertindas (Yusuf dan Bahari 2015).

Secara keseluruhan, adanya perbedaan seacara deskriptif ini mengonfirmasi pernyataan Ilyas (2018) bahwa fondasi teoritis TJSL sangat mirip dengan doktrin Islam atau syariah tentang keadilan sosial dan akuntabilitas. Demikian juga dengan Aribi dan Gao (2010) bahwa Islam mengajarkan manusia untuk menjaga keseimbangan dalam kehidupan, Dusuki dan Abdullah (2007) bahwa menerapkan nilai-nilai Islam atau syariah sudah dengan sendirinya menerapkan indikator-indikator dalam TJSL karena praktik TJSL konsisten dengan prinsip dan nilai syariah atau nilai Islami yang ditetapkan dalam Al Quran.

Dengan hasil pengujian statistik yang menunjukkan tidak adanya perbedaan signifikan pengungkapan TJSL antara bank syariah dan bank konvensional, maka hasil penelitian ini tidak mengonfirmasi Aribi dan Gao (2010) yang menemukan adanya perbedaan signifikan dalam pengungkapan TJSL antara bank Islam atau syariah dan bank konvensional. Demikian juga, hasil ini tidak sejalan dengan Yahya et al. (2004) serta Haniffa dan Hudaib (2007) yang menemukan tingkat pengungkapan aktivitas TJSL perusahaan berbasis syariah pada laporan tahunan cukup tinggi. Adanya perbedaan hasil ini kemungkinan disebabkan oleh karena nilai-nilai Islam atau syariah yang diterapkan pada bank syariah di Indonesia belum setinggi yang diterapkan pada bank Islam di Malaysia, Pakistan, Bangladesh, dan di negara-negara Timur Tengah di mana penelitian sebelumnya dilakukan.

Namun demikian, hasil penelitian ini sudah sejalan dengan Amran et al. (2017) yang menemukan bahwa pengungkapan TJSL oleh bank-bank Islam atau syariah umumnya tumbuh dengan baik di Malaysia dan Indonesia. Demikian juga dengan Scholtens (2009) yang menemukan bahwa pengungkapan TJSL pada sektor perbankan telah meningkat dalam beberapa tahun terakhir, walaupun dalam penelitian ini pengungkapan tersebut belum cukup tinggi. Masih belum maksimalnya pengungkapan TJSL ini tidak hanya berlaku pada sektor perbankan (Ullah dan Rahman, 2015), namun juga pada sektor bisnis lainnya yang ditemukan belum mencapai 50\% (Azim et al., 2011; Retno M. dan Priantinah, 2012; Burhany, 2011).

Pengungkapan TJSL yang relatif masih rendah terutama ditemukan pada negara yang belum memiliki regulasi yang ketat mengenai aktivitas dan pengungkapan TJSL sehingga pelaksanaannya lebih berifat voluntary atau semi voluntary. Jika regulasi sudah ada dan mapan, maka kemungkinan besar nilai pengungkapan TJSL akan tinggi. Justifikasi hasil penelitian ini adalah, regulasi berupa POJK Nomor 51/POJK.03/ 2017 tentang Penerapan Keuangan Berkelanjutan bagi Lembaga Jasa Keuangan, Emiten, dan Perusahaan Publik baru diundangkan pada tanggal 27 Juli 2017, sehingga belum menampakkan hasil yang signifikan dalam implementasinya mengingat penelitian ini mengambil data tahun 2018. 
Hasil analisis dan pengujian selanjutnya menemukan bahwa dari lima variabel yang diduga merupakan determinan pengungkapan TJSL, hanya satu yang terbukti berpengaruh terhadap pengungkapan TJSL yaitu karakteristik perusahaan berupa ukuran perusahaan. Sedangkan empat variabel lainnya yaitu karakteristik perusahaan berupa profitabilitas serta elemen tata kelola perusahaan berupa ukuran dewan direksi, independen, dan komite audit, tidak berpengaruh terhadap pengungkapan TJSL.

Dengan hasil ini maka dapat dijelaskan bahwa semakin besar ukuran bank yang dilihat dari aset yang dimiliki, maka semakin banyak pengungkapan TJSL yang dilakukannya. Ini mencerminkan bahwa aktivitas TJSL yang dilakukan juga banyak. Sebaliknya, semakin kecil ukuran perusahaan atau semakin sedikit asetnya, maka semakin sedikit pula pengungkapan TJSL yang dilakukan, yang mencerminkan bahwa aktivitas TJSL yang dilakukan juga sedikit. Dengan besarnya aset yang dimiliki maka bank akan menyisihkan aset tersebut untuk melakukan aktivitas TJSL untuk kemudian mengungkapkannya. Besarnya aset mencerminkan kemapanan suatu bank sehingga tidak ragu untuk memberikan perhatian kepada TJSL. Ukuran perusahaan sebagai determinan pengungkapan TJSL yang ditemukan pada penelitian ini mengonfirmasi kembali Gray et al. (1995); Hackston dan Milne (1996); Tagesson et al. (2009); Giannarakis (2014); Habbash (2016), yang menemukan bahwa ukuran perusahaan merupakan determinan positif atau berpengaruh positif terhadap pengungkapan TJSL.

Hasil yang menemukan profitablitas bukan determinan atau tidak berpengaruh terhadap pengungkapan TJSL, tidak mendukung Giannarakis (2014) yang menemukan bahwa profitabilitas berhubungan positif dengan pengungkapan TJSL. Namun hasil ini mendukung Habbash (2016) yang menemukan profitabilitas perusahaan tidak berpengaruh terhadap pengungkapan TJSL.

Sementara itu, variabel elemen tata kelola perusahaan yang ditemukan tidak satupun berpengaruh terhadap pengungkapan TJSL, menunjukkan bahwa pada bank syariah dan bank konvensional yang diteliti, elemen yang terdiri atas ukuran dewan direksi, direksi independen, dan komite audit tersebut bukan determinan pengungkapan TJSL. Dengan kata lain, ukuran dewan direksi yang besar (jumlah direksinya banyak), direksi independen yang rasionya lebih tinggi (lebih banyak direksi independen pada dewan direksi), dan komite audit yang besar (jumlah komisioner pada komite audit lebih banyak) bukan merupakan jaminan bahwa bank akan melakukan dan mengungkapkan lebih banyak TJSL. Elemen-elemen tersebut tidak memiliki arti apa-apa jika aset perusahaan tidak memadai untuk melakukan aktivitas TJSL dan kemudian mengungkapkannya.

Hasil ini tidak sejalan dengan Esa dan Ghazali (2012) yang menemukan ukuran dewan direksi berhubungan positif dengan luas pengungkapan TJSL serta Lone dan Khan (2016) yang menemukan ukuran dewan direksi dan direktur independen berpengaruh positif terhadap pengungkapan TJSL. Demikian juga dengan Said et al. (2009) yang menemukan komite audit berpengaruh positif terhadap luas pengungkapan TJSL. Namun hasil ini sejalan dengan Giannarakis (2014) yang menemukan ukuran dewan direksi tidak berhubungan dengan pengungkapan TJSL serta Habbash (2016) yang menemukan direksi independen dan komite audit tidak merupakan determinan atau tidak berpengaruh terhadap pengungkapan TJSL.

Bagaimanapun, secara keseluruhan, hasil penelitian ini kembali membuktikan kebenaran stakeholder theory yang menjelaskan bahwa perusahaan melakukan beberapa hal (termasuk pengungkapan TJSL) untuk memuaskan stakeholder karena membutuhkan dukungan untuk melanjutkan operasinya (Jensen dan Meckling, 1976; 
Gray et al., 1995; Donaldson, 1999). Demikian juga dengan legitimacy theory yang menjelaskan bahwa perusahaan membutuhkan legitimasi dari masyarakat agar mereka tidak dikenakan biaya politik jika tindakannya tidak disukai oleh masyarakat (Deegan dan Rankin, 1996; Hooghiemstra, 2000). Dengan melakukan pengungkapan TJSL, perusahaan mencoba membentuk citra positif dan menunjukkan identitas bertanggung jawab secara sosial. Pengomunikasian aktivitas TJSL menjadi saluran untuk menciptakan, memulihkan atau mempertahankan legitimasi perusahaan termasuk pada sektor perbankan, baik bank syariah maupun bank konvensional.

\section{SIMPULAN DAN SARAN}

Berdasarkan hasil penelitian dan pembahasan yang telah diuraikan, dapat disimpulkan bahwa: (1) Secara statistik, tidak ada perbedaan pengungkapan TJSL antara bank syariah dan bank konvensional. Namun secara deskriptif, pengungkapan TJSL pada bank syariah lebih tinggi dibandingkan pada bank konvensional; (2) Karakteristik perusahaan berupa ukuran perusahaan (aset) merupakan determinan yang berpengaruh positif terhadap pengungkapan TJSL pada bank syariah dan konvensional; (3) Karakteristik perusahaan berupa profitabilitas (ROA) serta elemen tata kelola perusahaan berupa ukuran dewan direksi, direksi independen, dan komite audit bukan merupakan determinan yaitu tidak berpengaruh terhadap pengungkapan TJSL pada bank syariah dan konvensional.

Saran yang diberikan berdasarkan hasil penelitian adalah: 1) Bank syariah dan bank konvensional perlu lebih meningkatkan lagi aktivitas TJSL yang diikuti dengan pengungkapan TJSL karena saat ini levelnya masih rendah; (2) Pemerintah melalui OJK perlu menindaklanjuti POJK No. 51/ POJK.03/2017 tentang Penerapan Keuangan Berkelanjutan bagi Lembaga Jasa Keuangan, Emiten, dan Perusahaan Publik, dengan melakukan pengawasan secara konsisten dan ketat beserta mekanisme reward dan punishment-nya agar aktivitas dan pengungkapan TJSL berjalan dengan maksimal dan memberikan manfaat berkelanjutan yang ditargetkan; (3) Peneliti selanjutnya disarankan untuk melakukan penelitian dengan data tahun 2019 setelah POJK No. 51/POJK.03/2017 berjalan lebih lama serta mengeksplor variabel determinan lainnya yang mungkin akan terbukti berpengaruh terhadap pengungkapan TJSL pada bank syariah dan bank konvensional.

\section{DAFTAR PUSTAKA}

Alam, S. M. S., S. M. S. Hoque, dan M. Z. Hosen. 2010. Corporate Social Responsibility (CSR) of MNCs in Bangladesh: A Case Study on GrameenPhone Ltd. Journal of Patuakhali Science and Technology University 2(1): 51-61.

Alimullah, M. M. 2006. Dynamics of Corporate Social Responsibility-Bangladesh Context. Journal of AIUB Bangladesh 3(1): 13-32.

Amran, A., H. Fauzi, Y. Purwanto, F. Darus, H. Yusoff, M. M. Zain, D. M. A. Naim, dan M. Nejati. 2017. Social Responsibility Disclosure in Islamic Banks: A Comparative Study of Indonesia and Malaysia. Journal of Financial Reporting and Accounting 15(1): 99-115.

Aribi, Z. A. dan S. Gao. 2010. Corporate Social Responsibility Disclosure: A Comparison between Islamic and Conventional Financial Institutions. Journal of Financial Reporting and Accounting 8(2): 72-91.

Azim, M. I., E. Ahmed, dan B. D'Netto. 2011. Corporate Social Disclosure in Bangladesh: A Study of the Financial Sector. International Review of Business Research Papers 7(2): 37-55.

Brammer, S. dan S. Pavelin. 2006. Voluntary Environmental Disclosures by Large UK Companies. Journal of Business Finance and Accounting 33(7-8): 11681188.

Buhr, N. dan M. Freedman. 2001. Culture, Institutional Factors and Differences in 
Environmental Disclosure Between Canada and the United States. Critical Perspectives on Accounting 12(3): 293322.

Burhany, D. I. 2011. Pengaruh Implementasi Akuntansi Lingkungan terhadap Kinerja Lingkungan dan Pengungkapan Informasi Lingkungan serta Dampaknya terhadap Kinerja Keuangan Perusahaan. Indonesian Journal of Economics and Business 1(2): 257-270.

Cowen, S. S., L. B. Ferreri, dan L. D. Parker. 1987. The Impact of Corporate Characteristics on Social Responsibility Disclosure: A Typology and FrequencyBased Analysis. Accounting, Organizations and Society 12(2): 111-122.

Deegan, C. dan B. Gordon. 1996. A Study of the Environmental Disclosure Practices of Australian Corporations. Accounting Business Research (26): 187-199.

Deegan, C. 2002. The Legitimising Effect of Social and Environmental Disclosures a Theoretical Foundation. Accounting, Auditing \& Accountability Journal 15(3): 282-311.

Deegan, C. dan C. Blomquist. 2006. Stakeholder Influence on Corporate Reporting: An Exploration of the Interaction between WWF-Australia and the Australian Minerals Industry. Accounting, Organizations and Society 31(4-5): 343-372.

Deegan, C. dan M. Rankin. 1996. Do Australian Companies Report Environmental News Objectively?: An Analysis of Environmental Disclosures by Firms Prosecuted Successfully by the Environmental Protection Authority. Accounting, Auditing \& Accountability Journal 9(2): 50-67.

Donaldson, T. 1999. Response: Making Stakeholder Theory Whole. The Academy of Management Review 24(2): 237241.

Dusuki, A. W. dan N. I. Abdullah. 2007. Why Do Malaysian Customers Patronise Islamic Banks? International Journal of
Bank Marketing 25(3): 142-160.

Elijido-Ten, E. 2007. Applying Stakeholder Theory to Analyze Corporate Environmental Performance: Evidence from Australian Listed Companies. Asian Review of Accounting 15(2): 164-184.

Esa, E. dan N. A. M. Ghazali. 2012. Corporate Social Responsibility and Corporate Governance in Malaysian GovernmentLinked Companies. Corporate Governance: The international journal of business in society 12(3): 292-305.

Farache, F. dan K. J. Perks. 2010. CSR Advertisements: A Legitimacy Tool? Corporate Communications 15(3): 235248.

Farook, S., M. K. Hassan, dan R. Lanis. 2011. Determinants of Corporate Social Responsibility Disclosure: The Case of Islamic Banks. Journal of Islamic Accounting and Business Research 2(2): 114-141.

Friedman, A. L. dan S. Miles. 2001. Socially Responsible Investment and Corporate Social and Environmental Reporting in the UK: An Explaratory Study. British Accounting Review 33(4): 523-548.

Gamerschlag, R., K. Möller, dan F. Verbeeten. 2011. Determinants of Voluntary CSR Disclosure: Empirical Evidence from Germany. Review of Managerial Science 5(2): 233-262.

Giannarakis, G. 2014. Corporate Governance and Financial Characteristic Effects on the Extent of Corporate Social Responsibility Disclosure. Social Responsibility Journal 10(4): 569-590.

Gray, R., R. Kouhy, dan S. Lavers. 1995. Corporate Social and Longitudinal Study of UK Disclosure. Accounting, Auditing $\mathcal{E}$ Accountability Journal 8(2): 47-77.

GRI. 2015. G4 Sustainability Reporting Guidelines.

Guthrie, J. dan I. Abeysekera. 2006. Content Analysis of Social, Environmental Reporting: What Is New? Journal of Human Resource Costing $\mathcal{E}$ Accounting 
10(2): 114-126.

Guthrie, J., S. Cuganesan, dan L. Ward. 2008. Industry Specific Social and Environmental Reporting: The Australian Food and Beverage Industry. Accounting Forum 32(1): 1-15.

Habbash, M. 2016. Corporate Governance and Corporate Social Responsibility Disclosure: Evidence from Saudi Arabia. Social Responsibility Journal 12: 740-754.

Hackston, D. dan M. J. Milne. 1996. Some Determinants of Social and Environmental Disclosures in New Zealand Companies. Accounting, Auditing \& Accountability Journal 9(1): 77-108.

Haniffa, R. dan M. Hudaib. 2007. Exploring the Ethical Identity of Islamic Banks via Communication in Annual Reports. Journal of Business Ethics 76(1): 97-116.

Hooghiemstra, R. 2000. Corporate Communication and Impression Management New Perspectives WHy Companies Engage in Corporate Social Reporting. Journal of Business Ethics 27(1): 55-68.

Ilyas, M. 2018. Islamic Work Ethics and Corporate Social Responsibility in Business Organizations. Academy of Accounting and Financial Studies Journal 22: 1-6.

Islam, A. M. dan C. Deegan. 2008. Motivations for an Organisation within a Developing Country to Report Social Responsibility Information: Evidence from Bangladesh. Accounting, Auditing and Accountability Journal 21(6): 850-874.

Jensen, M. C. dan W. H. Meckling. 1976. Theory of the Firm: Managerial Behaviour, Agency Costs and Ownership Structure. Journal of Financial Economics 19: 127-168.

Khan, H. U. Z. 2010. The Effect of Corporate Governance Elements on Corporate Social Responsibility (CSR); Reporting: Empirical Evidence from Private Commercial Banks of Bangladesh. International Journal of Law and Management 52(2): 82-109.
Kolk, A. 2003. Trends in Sustainability Reporting by the Fortune Global 250. Business Strategy and the Environment 12(5): 279-291.

Kolk, A., S. Walhain, dan S. V. D. Wateringen. 2001. Environmental Reporting by the Fortune Global 250: Exploring the Influence of Nationality and Sector. Business Strategy and the Environment 10(1): 15-28.

Lone, E. J. dan A. A. I. Khan. 2016. Corporate Governance and Corporate Social Responsibility Disclosure: Evidence from Pakistan. Corporate Governance: The International Journal of Business in Society 16(45): 785-797.

Moneva, J. M., dan F. Llena. 2000. Environmental Disclosures in the Annual Reports of Large Companies in Spain. European Accounting Review 9(1): 7-29.

Patten, D. M. 2002. The Relation between Environmental Performance and Environmental Disclosure: A Research Note. Accounting, Organizations and Society 27(8): 763-773.

Rashid, M., I. Abdeljawad, S. M. Ngalim, dan M. K. Hassan. 2013. Customer-Centric Corporate Social Responsibility: A Framework for Islamic Banks on Ethical Efficiency. Management Research Review 36(4): 359-378.

Retno M., R. D. dan D. Priantinah. 2012. Pengaruh Good Corporate Governance Dan Pengungkapan Corporate Social Responsibility Terhadap Nilai Perusahaan (Studi Empiris Pada Perusahaan Yang Terdaftar Di Bursa Efek Indonesia Periode 2007-2010). Jurnal Nominal 1(1): 84-103.

Said, R., Y. Zainuddin, dan H. Haron. 2009. The Relationship between Corporate Social Responsibility Disclosure and Corporate Governance Characteristics in Malaysian Public Listed Companies. Social Responsibility Journal 5(2): 212226.

Scholtens, B. 2009. Corporate Social Responsibility in the International Banking Industry. Journal of Business Ethics 86(2): 
159-175.

Shaumya, S. dan A. Arulrajah. 2017. The Impact of Green Banking Practices on Banks Environmental Performance: Evidence from Sri Lanka. Journal of Finance and Bank Management 5(1): 7790.

Tagesson, T., V. Blank, P. Broberg, dan S. O. Collin. 2009. What Explains the Extent and Content of Social Disclosures on Corporate Websites? Corporate Social Responsibility and Environmental Management 16(March): 352-364.

Ullah, M. H. dan M. A. Rahman. 2015. Corporate Social Responsibility Reporting Practices in Banking Companies in Bangladesh: Impact of Regulatory Change. Journal of Financial Reporting and Accounting 13(2): 200-225.

Vilar, V. H. dan J. Simão. 2015. CSR Disclosure on the Web: Major Themes in the Banking Sector. International Journal of Social Economics 42(3): 296318.
Waller, D. S. dan R. Lanis. 2009. Corporate Social Responsibility (CSR) Disclosure of Advertising Agencies: An Exploratory Analysis of Six Holding Companies Annual Reports. Journal of Advertising 38(1): 109-122.

Yahya, M. A., A. A. Rahman, dan M. Tayib. 2004. The Relationship between Corporate Social Disclosure and Islamic Unit Trust Shareholdings. Accounting, Commerce and Finance: The Islamic Perspective Journal 9(1).

Yusuf, M. Y. dan Z. B. Bahari. 2015. Islamic Corporate Social Responsibility in Islamic Banking: Towards Poverty Alleviation. In Ethics, Governance and Regulation in Islamic Finance 4: 73-90. 